\title{
Expedition 303/306 synthesis: North Atlantic climate ${ }^{1}$
}

\author{
J.E.T. Channell, ${ }^{2}$ T. Sato, ${ }^{3}$ T. Kanamatsu, ${ }^{4}$ R. Stein, ${ }^{5}$ and C. Alvarez Zarikian ${ }^{6}$
}

\section{Chapter contents}

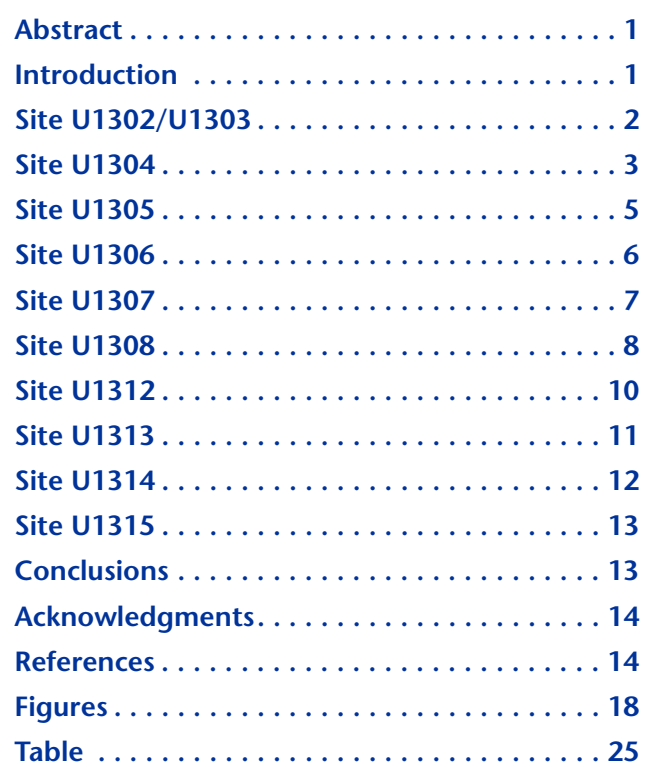

${ }^{1}$ Channell, J.E.T., Sato, T., Kanamatsu, T., Stein, R., and Alvarez Zarikian, C., 2010. Expedition 303/ 306 synthesis: North Atlantic climate. In Channell, J.E.T., Kanamatsu, T., Sato, T., Stein, R., Alvarez Zarikian, C.A., Malone, M.J., and the Expedition 303/306 Scientists, Proc. IODP, 303/306: College Station, TX (Integrated Ocean Drilling Program Management International, Inc.).

doi:10.2204/iodp.proc.303306.214.2010

2Department of Geological Sciences, University of Florida, Gainesville FL 32611, USA.

jetc@ufl.edu

${ }^{3}$ Department of Earth Sciences and Technology, Akita University, Akita 010-8502, Japan.

${ }^{4}$ Institute for Frontier Research on Earth Evolution, Japan Agency for Marine-Earth Science and Technology, Yokosuka 237-0061, Japan.

${ }^{5}$ Alfred-Wegener-Institut für Polar und

Meeresforschung, Columbusstrasse 2, 27568

Bremerhaven, Germany.

${ }^{6}$ Integrated Ocean Drilling Program, Texas A\&M University, 1000 Discovery Drive, College Station TX 77845-9547, USA.

\section{Abstract}

The sites occupied during Integrated Ocean Drilling Program Expedition 303/306 were chosen to recover late Miocene to Quaternary records of North Atlantic environmental variability at elevated mean sedimentation rates from locations appropriate for oxygen isotope $\left(\delta^{18} \mathrm{O}\right)$ and relative paleointensity (RPI) stratigraphies. The overall objective is to correlate these climate/paleoceanographic records to two (ostensibly) independent global stratigraphic signals $\left(\delta^{18} \mathrm{O}\right.$ and $\left.\mathrm{RPI}\right)$, thereby enhancing stratigraphic resolution. One site at Orphan Knoll (Site U1302/U1303) provided a proximal record of Laurentide Ice Sheet instability for the Brunhes Chron. Three sites from the Eirik Drift (Sites U1305, U1306, and U1307) provided records of the strength and location of the Western Boundary Undercurrents well as monitors of Greenland Ice Sheet instability back into the Pliocene. Poor weather over the Erik Drift during the second phase of drilling (Expedition 306) precluded the planned return that would have further enhanced knowledge of the history of the drift. Three sites (U1308, U1312, and U1313) constituted reoccupations of classic paleoceanographic sites drilled in 1983 during Deep Sea Drilling Project Leg 94. Although poor weather compromised the record at Site U1312, the new drilling at Sites U1308 and U1313 provided complete sections to the Pliocene and late Miocene, respectively, that were not available from Leg 94. Site U1308 provided evidence for "Hudson Strait" Heinrich Events in the eastern North Atlantic from the end of the middle Pleistocene transition ( $640 \mathrm{ka})$. One site on the central part of the Gardar Drift (Site U1314) and one site at the southern tip of the Gardar Drift (Site U1304) provided high-resolution deepwater paleoceanographic records that can be linked with shallower water drift sites in the Iceland Basin, drilled during Ocean Drilling Program Leg 162. Site U1315, located on the Vøring Plateau, was drilled to 179 meters below seafloor. Instruments to monitor seafloor temperature variations resulting from bottom current changes were installed with a circulation obviation retrofit kit to seal the borehole.

\section{Introduction}

The sites occupied during Integrated Ocean Drilling Program (IODP) Expedition 303/306 (Fig. F1; Table T1) were chosen to recover Miocene to Quaternary records of North Atlantic environmental variability in terms of ice sheet-ocean interactions, deep circula- 
tion changes, or sea-surface conditions. The sites provide the requirements, including adequate sedimentation rates, for developing high-resolution stratigraphies through geomagnetic relative paleointensity (RPI), oxygen isotopes, and regional environmental patterns (see the "Expedition 303 summary" and "Expedition 306 summary" chapters; Channell et al., 2006).

The timing of the two drilling expeditions, separated by an interval of 5 months, allowed experience from the first expedition (Expedition 303: SeptemberNovember 2004) to be incorporated in the plan for the second expedition (Expedition 306: March-May 2005). Results of the first expedition did indeed lead to a revised drilling plan for the second expedition, particularly for the Eirik Drift off southeast Greenland. In this region, cores recovered during Expedition 303, combined with the multichannel seismic data acquired in 2002, allowed a refined choice of sites. Unfortunately, poor weather conditions during Expedition 306 precluded the ship reaching the Eirik Drift.

Nonetheless, the sites occupied during Expeditions 303 and 306 provided a rich archive of Miocene to Quaternary environmental conditions from the North Atlantic. At the outset, the decision was made to limit drilling to depths achievable using the advanced piston corer (APC), the rationale being that the extended core barrel (XCB) does not provide adequate core quality for planned high-resolution studies. Recovery of complete composite sections through shipboard control of hole-to-hole offsets was given high priority.

The North Atlantic has been the focus of some of the most intriguing advances in paleoceanography in the last $20 \mathrm{y}$, including the recognition of Heinrich layers and Bond cycles and the proposed $\sim 1500 \mathrm{y}$ pacing in ice-rafted debris (IRD) proxies such as hematite-stained grains and Icelandic glass (Broecker et al., 1992; Bond et al., 1992, 1999, 2001). These observations have been largely restricted to the last glacial cycle because of the lack of high sedimentationrate records with known continuity that extend beyond the last glacial cycle. A principal objective of Expedition 303/306 was to obtain sedimentary records that would extend our knowledge of millennial-scale paleoceanographic change beyond the last glacial cycle, through the so-called "100 k.y. world" and into the "41 k.y. world." The critical role of age control in interpreting these paleoceanographic phenomena, particularly beyond the range of radiocarbon dating and the Greenland ice core record, requires that sites be appropriate not only for oxygen isotope stratigraphy but also for more recently developed stratigraphies based on RPI studies.
A summary of the polarity stratigraphies and biostratigraphies obtained from sites occupied during Expedition 303/306 are given in Figure F2. Sites from Orphan Knoll (Site U1302/U1303), Eirik Drift (Site U1305/U1306), and Gardar Drift (Site U1314) yielded records covering the last $\sim 1-2 \mathrm{~m} . \mathrm{y}$., at mean sedimentation rates of $10-20 \mathrm{~cm} / \mathrm{k} . \mathrm{y}$. Shipboard hole-to-hole correlations indicate that complete composite sections can be constructed for large parts of the sedimentary records recovered at these sites (Table T1). At Sites U1308 and U1313, two previously drilled North Atlantic sites (Deep Sea Drilling Project [DSDP] Sites 609 and 607, respectively) were reoccupied to obtain composite sections for sites that lie in the heart of the North Atlantic "Ruddiman" (1977) IRD belt (Site U1308) and at the southern edge of the belt (Site U1313). Sites 607 and 609 have provided key records of Pliocene to Quaternary North Atlantic paleoceanography (Ruddiman et al., 1986, 1989; Raymo et al., 1989), and the objective of reoccupation of these sites was to obtain demonstrably complete sections that would lend themselves to analytical methods developed since the sites were drilled over $25 \mathrm{y}$ ago. At these two sites (U1308 and U1313), mean sedimentation rates are $4-10 \mathrm{~cm} / \mathrm{k} . \mathrm{y}$., and the recovered sections extend back to 3.2 and $5 \mathrm{Ma}$, respectively. Site U1312 on the southern flank of the King's Trough constituted a redrill of DSDP Site 608 with the principal target being the classic upper Miocene section (e.g., Miller et al., 1991). Unfortunately, severe weather conditions resulted in a high degree of drilling disturbance in the recovered cores that precluded the construction of a composite section at this site and resulted in its premature abandonment. Site U1315 was drilled at the site of Ocean Drilling Program (ODP) Site 642 to 179 meters below seafloor (mbsf) and cased to receive a $150 \mathrm{~m}$ thermistor string for monitoring bottom water temperatures and seafloor diffusion over a multiyear period.

\section{Site U1302/U1303}

The overall objective at Site U1302/U1303 is to explore the record of Laurentide Ice Sheet (LIS) instability at this location close to Orphan Knoll (Fig. F1). Piston cores collected nearby (Cores HU91-045-094P, MD99-2237, and MD95-2024) show the presence of numerous detrital layers within the last glacial cycle, some of which are rich in detrital carbonate (HillaireMarcel et al., 1994; Stoner et al., 1995, 1996; Hiscott et al., 2001). The correlation of these detrital layers to the classic Heinrich layer stratigraphy and to other central Atlantic detrital layers (e.g., Bond and Lotti, 1995) remains problematic. Oxygen isotope data from planktonic foraminifers imply that these detrital layers are often associated with low-productivity meltwater 
pulses (Hillaire-Marcel et al., 1994). The Heinrichtype detrital layers usually appear as lighter colored intervals, particularly where they are rich in detrital carbonate. The detrital layers are often evident in magnetic susceptibility and gamma ray attenuation (GRA) density data measured on the shipboard multisensor track (MST). The objective at Sites U1302 and U1303 is to document this manifestation of LIS instability both during and prior to the last glacial cycle, beyond the reach of previously existing piston cores.

Sites U1302 and U1303 are separated by $5.68 \mathrm{~km}$. The move to a different location from Site U1302 was an effort to avoid a debris flow at 110 mbsf that halted drilling at both sites. An almost complete composite section was constructed at Site U1302 spanning 0-107 meters composite depth (mcd). Although it was not possible to construct a complete composite record at Site U1303, the density and magnetic susceptibility records from Sites U1302 and U1303 are remarkably similar and can be easily correlated. A short segment from one core of Site U1303, together with the record from Site U1302, provides a continuous composite stratigraphic sequence to $\sim 107 \mathrm{mcd}$.

Sediments at Sites U1302 and U1303 are dominated by varying mixtures of terrigenous components and biogenic debris (primarily quartz, detrital carbonate, and nannofossils); the most common lithologies are clay and nannofossil ooze with silty clay. Dropstones are present throughout the cores. Calcium carbonate content ranges from 1 to $47 \mathrm{wt} \%$. At the base of the sediment sequence, debris flow deposits (106$132 \mathrm{mcd}$ ) contain abundant intraclasts in a matrix of sand-silt-clay.

Samples from Site U1302 contain rich assemblages of calcareous, siliceous, and organic-walled microfossils. Coccoliths are abundant and well preserved in most samples and permit establishment of biostratigraphic schemes that are complemented by a few datums from diatoms and palynological data. The micropaleontologic assemblages provide insight into paleoclimatologic and paleoceanographic conditions. In particular, the relative abundance of the planktonic foraminifer Neogloboquadrina pachyderma (sinistral) and some dinocyst assemblages allows identification of glacial and interglacial conditions. The diatom assemblage in the upper $48 \mathrm{~m}$ at this site has been studied by Romero.

The pore water chemistry from Sites U1302 and $\mathrm{U} 1303$ is dominated by reactions associated with organic matter degradation, despite the relatively low organic matter content of the sediments ( $0.5 \mathrm{wt} \%)$. Sulfate concentration decreases from seawater value to $5.9 \mathrm{mM}$ close to the base of the recovered section, indicating that sulfate reduction is almost complete by 109 mcd.

Benthic foraminifers are rare at this site, although a continuous planktonic oxygen isotope record for the Brunhes Chron has been acquired using N. pachyderma (sinistral) (Hillaire-Marcel et al., pers comm., 2009). Shore-based U-channel paleomagnetic data have shown that the Matuyama/Brunhes boundary is recorded just above the debris flow at $105 \mathrm{mcd}$, yielding a mean Brunhes sedimentation rate of $13.5 \mathrm{~cm} / \mathrm{k} . \mathrm{y}$. (Channell et al., 2009a). Several magnetic excursions are recorded within the Brunhes Chron, including the Iceland Basin excursion at $188 \mathrm{ka}$, providing further stratigraphic markers and extending the inventory of magnetic excursions in the North Atlantic. The RPI record (Channell et al., 2009a) can be correlated to the oxygen isotope record to provide high-resolution age control throughout the record.

The detrital layer stratigraphy, recognized for the last glacial cycle in conventional piston cores from close to the site (e.g., Cores HU91-045-094P, MD99-2237, and MD95-2024), can be recognized using a variety of parameters including GRA density measurements, $\mathrm{Ca} / \mathrm{Sr}$ ratios from X-ray fluorescence (XRF) core scanning, and magnetic hysteresis properties. The $\mathrm{Ca} / \mathrm{Sr}$ ratio derived from XRF core scanning provides an efficient means of recognizing detrital carbonate associated with Heinrich-type detrital layers derived from Hudson Strait (Hodell et al., 2008). Comparison of the $\mathrm{Ca} / \mathrm{Sr}$ ratio with GRA density and magnetic hysteresis and susceptibility data allows detrital carbonate events to be differentiated from low detrital carbonate events.

The acquisition of oxygen isotope and RPI data from Site U1302/U1303 provides a stratigraphic resolution that permits the proximal record of detrital layers obtained from Orphan Knoll to be correlated to the distal record at Site U1308 (Fig. F1). The correlation of detrital layers across the North Atlantic, particularly beyond the last glacial cycle, has been stymied by the lack of stratigraphic precision that has not allowed unequivocal correlation of detrital layers and hampered the understanding of distribution and provenance of detrital layers in the North Atlantic (e.g., van Kreveld et al., 1996).

\section{Site U1304}

The objective at Site U1304 was to obtain a deep water record from the southern edge of the Gardar Drift (Fig. F1; Table T1) to compare with the intermediate depth site on the northern part of the Gardar Drift sampled during ODP Leg 162 at Site 983. Site U1304 is north of the Charlie Gibbs Fracture Zone, $217 \mathrm{~km}$ west-northwest of DSDP Site 611. The mean sedi- 
mentation rate at Site U1304 $(15 \mathrm{~cm} / \mathrm{k} . \mathrm{y}$.$) is about six$ times that in the same stratigraphic interval at DSDP Site 611.

Four holes were cored with the APC coring system to a maximum depth of $243.8 \mathrm{mbsf}$ at Site U1304. Correlation of cores among holes at Site U1304, utilizing mainly magnetic susceptibility and natural gamma radiation, provides a continuous stratigraphic sequence to $\sim 258$ mcd with a single potential break within an $8 \mathrm{~m}$ thick diatom mat at $\sim 199 \mathrm{mcd}$. The spliced composite section relies on sections from Holes U1304A and U1304B because good weather conditions during the early occupation of Site U1304 led to excellent recovery and good core quality.

The sediments at Site U1304 are predominantly interbedded diatom oozes and nannofossil oozes with less common intervals of clay and silty clay that also contain abundant nannofossils and/or diatoms. Calcium carbonate content ranges from 5 to $70 \mathrm{wt} \%$ and organic carbon content is low (generally $<0.5 \mathrm{wt} \%$ ). This sedimentary succession has been designated as a single unit because the various lithologies are generally interbedded on a scale of only centimeters to decimeters. Most contacts between nannofossil ooze and clay intervals are gradational, although sharp contacts are also observed. The contacts between diatom ooze beds and the other lithologies are generally sharp. Redeposited beds of silt and sand-sized particles are rare, as are disturbed units related to mass-transport processes (e.g., slumps and debris flows). Thus, the section cored at Site U1304 apparently represents a relatively continuous pelagic section, where the sediments record changes in productivity in response to oceanographic and climatic conditions.

Recurring laminated diatom sequences are the most prominent feature at Site U1304 (Shimada et al., 2008). The thicker diatom mats are clearly distinguished by very low magnetic susceptibility values. Diatom assemblages are dominated by needleshaped species of the Thalassiothrix/Lioloma complex. All other fossil groups investigated, coccoliths, planktonic and benthic foraminifers, radiolarians, and palynomorphs, are present in high to moderate abundance and are well preserved (see Liu; Yamasaki et al., 2008). Biostratigraphic datums were mainly derived from coccoliths and are consistent with datums provided by diatoms, planktonic foraminifers, dinoflagellate cysts, and magnetostratigraphy. The composite sequence covers the uppermost Pliocene and the entire Quaternary. The microfossil assemblage indicates only minor redeposition. Excellent preservation of benthic and planktonic microfossils enhances the potential for a high-resolution environmental record. The site monitors North Atlantic
Deep Water (NADW) and sea-surface temperatures and may provide a record of central Atlantic detritallayer stratigraphy. Oxygen isotope stratigraphies based on both planktonic and benthic foraminifers are presently in development for this site. Published stable isotope data at Site U1304 has demonstrated that the site provides a particularly high resolution record of the last interglacial, where sedimentation rates were $\sim 40 \mathrm{~cm} / \mathrm{k} . \mathrm{y}$., where frequent thin diatomrich layers inhibit bioturbation (Hodell et al., 2009). Planktonic oxygen isotope data from a number of planktonic foraminifer species are compared with benthic oxygen and carbon isotope data, yielding a unique picture of surface and deep water evolution during marine isotope stage (MIS) 5 (Hodell et al., 2009). The results from this study of MIS 5 at Site U1304 illustrate the potential of the site for detailed studies of Quaternary paleoceanography.

Preliminary paleoceanographic interpretation of the microflora and microfauna reveals large-amplitude changes in surface water temperature and trophic conditions. Diatom layers were formed during both cold and warm phases, according to interpretation of diatom and planktonic foraminifer assemblages (Shimada et al., 2008). The presence of the benthic foraminifer Epistominella exigua documents recurring flux pulses of fresh organic matter to the seafloor. A shift from dominance of autotrophic to heterotrophic dinocyst assemblages is recorded after $1.2 \mathrm{Ma}$, which may suggest a general change in trophic conditions of the surface ocean.

Site U1304 sediments document a magnetostratigraphic sequence that includes the Brunhes Chron and part of the Matuyama Chron, the Jaramillo and Cobb Mountain Subchrons, and the top of the Olduvai Subchron. Mean sedimentation rates of $17.8 \mathrm{~cm} / \mathrm{k} . \mathrm{y}$. are estimated for the last $0.78 \mathrm{~m} . \mathrm{y}$. and $12.2 \mathrm{~cm} / \mathrm{k} . \mathrm{y}$. for the interval from 0.78 to $1.77 \mathrm{Ma}$, with an overall mean sedimentation rate of $14.9 \mathrm{~cm} / \mathrm{k} . \mathrm{y}$. The shorebased magnetic stratigraphy has resolved two magnetic excursions at this site and has refined the position of the major reversals (C. Xuan and J.E.T. Channell, unpubl. data). The RPI record at this site is in the process of being developed and awaits correlation to the oxygen isotope records.

Site U1304 pore water profiles indicate active sulfate reduction (minimum value of $2.8 \mathrm{mM}$ reached at $214 \mathrm{mbsf}$ ) with corresponding increases in alkalinity and ammonium, although alkalinity values do not reach concentrations expected for the degree of sulfate reduction. Calcium concentrations decrease downcore to $2.7 \mathrm{mM}$, a $\sim 75 \%$ reduction from standard seawater values.

The Quaternary sequence recovered at Site U1304 provides a high-resolution, high-sedimentation rate 
(average $\sim 15 \mathrm{~cm} / \mathrm{k} . \mathrm{y}$.$) record of environmental$ change at a sensitive location close to the sub-Arctic convergence between the surface Labrador Current and the North Atlantic Current (see Bodén and Backman, 1996). Good preservation of both calcareous and siliceous microfossils, abundant benthic foraminifers, and a high-fidelity magnetostratigraphic record indicate that the environmental record, including monitoring of NADW, can be placed in a tight chronological framework based on oxygen isotope and RPI data.

\section{Site U1305}

Site U1305 is located close to the southwest extremity of the Eirik Drift, $82.2 \mathrm{~km}$ south of ODP Site 646 (Fig. F1; Table T1). The thickness of the sediments above the mid-upper Pliocene seismic Reflector R1 $(\sim 540 \mathrm{~m})$ is almost twice that at Site 646 . The water depth $(3518 \mathrm{~m})$ means that the seafloor at Site U1305 lies below the main axis of the Western Boundary Undercurrent (WBUC) and hence preserves expanded interglacial intervals and relatively condensed glacial intervals. The mean Quaternary sedimentation rate $(>17 \mathrm{~cm} / \mathrm{k} . y$.$) provides a high-$ resolution record of ice sheet instability, and changes in surface and deep water masses.

Three holes were cored at Site U1305 with the APC system to a maximum depth of 287 mbsf. The sediments at Site U1305 are designated as a single unit dominated by varying mixtures of terrigenous components and biogenic material, primarily clay minerals, quartz, detrital carbonate, and nannofossils. Calcium carbonate content ranges from 1 to $49 \mathrm{wt} \%$. The most common lithologies are dark gray to very dark gray silty clay and nannofossil ooze with silty clay. In addition, olive-gray sandy silt laminae and centimeter- to decimeter-scale intervals of silty clay with detrital carbonate are present. The sediments are gradationally interbedded at scales of a few meters or less.

Calcareous, siliceous, and organic-walled microfossils show generally good preservation and abundance in the upper $\sim 200 \mathrm{mcd}$. However, the abundance of microfossil assemblages is variable below this depth, with generally poorer preservation. All microfossil groups investigated are dominated by subpolar to polar assemblages. Planktonic foraminifers show a bimodal size distribution. The small test-sized planktonic foraminifers, which are cold-water species, coexist with increased abundance of benthic foraminifers, possibly indicating transport by bottom currents. An oxygen isotope stratigraphy based on $N$. pachyderma (sinistral) is presently in development (C. Hillaire-Marcel, pers. comm., 2009).
Sediments at Site U1305 carry well-defined magnetization components and appear to provide useful records of polarity transitions. Natural remanent magnetization (NRM) intensities decrease by about one-half below 166 mcd. Directional magnetization data allow identification of the Brunhes Chron and part of the Matuyama Chron, including the Jaramillo, Cobb, and Olduvai Subchrons. The Cobb Mountain Subchron and the top of the Olduvai Subchron are less clearly identified because of the incomplete removal of the normal polarity drill string magnetic overprint. A relative paleointensity record is presently being developed for this site (A. Mazaud, pers. comm., 2009).

A continuous stratigraphic composite section was constructed to $\sim 295$ mcd with a single problematic interval between 197.2 and 206 mcd. The mean sedimentation rate calculated using biostratigraphic and magnetostatigraphic datums is $17.5 \mathrm{~cm} / \mathrm{k}$.y. for the entire section. Using only paleomagnetic datums, sedimentation rates are relatively uniform with the exception of a higher mean sedimentation rate between 1.07 and $1.19 \mathrm{Ma}$ (from the base of the Jaramillo to the top of the Cobb Mountain Subchrons) that averages $29.3 \mathrm{~cm} / \mathrm{k} . \mathrm{y}$.

Despite the low organic carbon content (mean $<0.4 \mathrm{wt} \%$ ), organic matter diagenesis dominates the pore water chemistry (see Ennyu and Malone). Sulfate decreases linearly downcore and is completely reduced by 58 mbsf. Methane increases immediately below the sulfate reduction zone, reaching a maximum of 46,000 ppmv at 228 mbsf. Ethane fluctuates between 2 and $14 \mathrm{ppmv}$ within the methanogenic zone, but no higher hydrocarbons were detected. Alkalinity increases downcore, reaching a maximum of $18.9 \mathrm{mM}$ at the sulfate/methane interface (SMI). Calcium reaches a minimum of $2.58 \mathrm{mM}$ at the same depth, suggesting carbonate precipitation associated with anaerobic methane oxidation at the SMI. Similar to other Expedition 303 sites, dissolved strontium at Site U1305 is at or below seawater values, indicating little or no carbonate dissolution or recrystallization.

Physical property records at Site U1305, in particular magnetic susceptibility and density, are highly variable, recording lithologic and mineralogic changes. Low magnetic susceptibility and density values usually coincide with the presence of silt-sized detrital carbonate. The detrital carbonate (Heinrich-type) layers are characterized by a very specific biomarker association, pointing to an Ordovician oil shale close to Hudson Strait as the source of these layers (Hefter et al., 2007). Natural gamma radiation (NGR) increases at the transition between detrital carbonateand siliciclastic-dominated background sediments, 
suggesting a relative increase in the clay component. Site U1305 sediments are also characterized by an overall downcore increase in density (from 1.3 to $\sim 1.9 \mathrm{~g} / \mathrm{cm}^{3}$ ), decreasing porosity (from $80 \%$ to $62 \%$ ), and low $P$-wave velocities $(1500-1600 \mathrm{~m} / \mathrm{s})$.

Data from wireline logs in Hole U1305C span the interval from 95.3 to 265.9 mbsf. The triple combination (triple combo) tool string was successfully deployed, yielding downhole records of density, porosity, NGR, electrical resistivity, and photoelectric factor. Density and porosity are generally inversely related, with density increasing and porosity decreasing downhole. Density and gamma ray logging data show similar downhole trends to those observed in core data.

The analysis of MST, biostratigraphic, and paleomagnetic data indicates that a complete and continuous high-resolution record (mean sedimentation rate $=$ $17.3 \mathrm{~cm} / \mathrm{k} . \mathrm{y}$.$) , covering the uppermost Pliocene and$ Quaternary, has been recovered at Site U1305. The record represents a rich archive of environmental change that documents episodes of instability in the surrounding (Laurentide, Greenland, and Inuitian) ice sheets, the history of surface currents and deep water currents, and hence the strength of the WBUC that contributes to NADW. Good preservation of both planktonic and benthic foraminifers for isotopic analysis and a high-fidelity paleomagnetic record indicate that the environmental record can be integrated into a high-resolution stratigraphy.

\section{Site U1306}

At Site U1306, late Pliocene and Quaternary mean sedimentation rates were estimated to be $\sim 18 \mathrm{~cm} / \mathrm{k} . \mathrm{y}$., based on identification of seismic Reflector R1, which can be correlated to the mid-upper Pliocene at Site 646. The placement of the site was designed to yield a high-resolution (high sedimentation rate) Quaternary environmental record from a water depth within the main axis of the WBUC. Based on a nearby conventional piston core from a similar water depth (Core HU90-013-012; Hillaire-Marcel et al., 1994), we expect glacial intervals to be expanded relative to interglacial intervals.

Four holes were cored with the APC system at Site U1306, reaching a maximum depth of 309.3 mbsf. Hole U1306D was cored to 180.0 mbsf to provide necessary stratigraphic overlap for the upper portion of the sediment sequence. Five cores were obtained by drillover, and the average recovery was $102.5 \%$ for the cored interval.

The sediments at Site U1306 are designated as a single lithostratigraphic unit, composed of Holocene to uppermost Pliocene terrigenous and biogenic sediments that are gradationally interbedded at scales of a few meters or less. Calcium carbonate content is low, ranging from 0.3 to $12.3 \mathrm{wt} \%$ (mean $=3.2 \mathrm{wt} \%)$. The most common lithologies are silty clay, silty clay with diatoms, nannofossil silty clay, and silty clay nannofossil ooze. Dropstones are present throughout the cored interval, and large dropstones $(\sim 4 \mathrm{~cm})$ are common to abundant. Centimeter- to decimeterscale beds of olive-gray or greenish gray silty clay or clay with a high detrital carbonate content are present in all holes at Site U1306, but they are thinner and less common than at Site U1305.

Rich assemblages of calcareous, siliceous, and organicwalled microfossils are present at Site U1306, although benthic foraminifers are barren in many samples below $175 \mathrm{mcd}$. An oxygen isotope record based on N. pachyderma (sinistral) is presently in development (J.D. Wright, pers. comm., 2010). Large variations in abundance of microfossils occur downcore. Although preservation is moderate to good in the upper part of the succession, preservation generally decreases below $\sim 170$ mcd for calcareous and siliceous microfossils. All samples contain moderately well to well-preserved palynomorphs but variable numbers of dinocysts, which are abundant only in a few samples. Some redeposition is indicated by the presence of reworked nannofossils and palynomorphs of Cretaceous to Miocene age through the cored interval. The dominant components of each microfossil group reflect cold sea-surface temperatures (SSTs) for most of the time represented by the sedimentary sequence.

The sediments at Site U1306 carry well-defined magnetization components and document an apparently continuous sequence including the Brunhes Chron and much of the Matuyama Chron. The Jaramillo, Cobb Mountain, and Olduvai Subchrons are clearly identified. Within the Brunhes Chron, the Iceland Basin magnetic excursion ( 188 ka) was observed in three of the holes.

A continuous stratigraphic composite section was constructed to $\sim 337 \mathrm{mcd}$. Below $287 \mathrm{mcd}$, cores were recovered in two holes only, but the section is complete with only a single tenuous tie near the base of the record. The mean sedimentation rate, calculated using biostratigraphic and magnetostatigraphic datums, is $15.6 \mathrm{~cm} / \mathrm{k} . \mathrm{y}$. for the entire section cored at Site U1306. Using only paleomagnetic datums, interval sedimentation rates vary between 12.4 and $19.3 \mathrm{~cm} / \mathrm{k} . \mathrm{y}$.

Pore water chemical profiles at Site U1306 document very similar reactions to nearby Site U1305 (see Ennyu and Malone). Complete sulfate reduction is achieved at shallow depths at Site U1306 (85 mbsf) 
despite the low organic carbon content (mean = $0.3 \mathrm{wt} \%$ ). Methane increases below $85 \mathrm{mbsf}$, reaching a maximum of $46,000 \mathrm{ppmv}$. Alkalinity reaches a maximum of $18.7 \mathrm{mM}$ at the SMI, whereas calcium concentration attains a minimum value $(3.7 \mathrm{mM})$, indicating carbonate mineral precipitation associated with methane oxidation. From 114 to 258 mbsf, sulfate increases slightly again $(1.5 \mathrm{mM})$. This interval corresponds to $\mathrm{pH}$ and iron fluctuations, which are antithetic to each other and may indicate zones of anaerobic pyrite oxidation. Dissolved strontium remains at or below seawater values suggesting little or no carbonate dissolution or recrystallization.

Physical property records at Site U1306 are highly variable, recording lithologic and mineralogic changes. The higher carbonate content in the upper 100 mcd results in lower NGR and magnetic susceptibility values than in the sediments below. Site U1306 sediments are characterized by an overall downcore increase in density $\left(1.5\right.$ to $\left.\sim 1.8 \mathrm{~g} / \mathrm{cm}^{3}\right)$ and decreasing porosity ( 70\% to $50 \%)$.

Based on nearby piston cores, Site U1306 is expected to exhibit expanded glacial intervals, complementary to Site U1305 where interglacials are likely to be relatively expanded. The apparently complete Quaternary record recovered at Site U1306 provides a high-resolution (high sedimentation rate) record of detrital events derived from the instability of surrounding ice sheets. The site monitors the activity of the WBUC, which supplies a component of NADW to the Labrador Sea, and appears to have the attributes required for the generation of a well-constrained age model based on oxygen isotopes, micropaleontology, and RPI.

\section{Site U1307}

The location of Site U1307 was chosen for access to Pliocene sediments below the Quaternary sequence drilled at Site U1306. A thinner Quaternary sedimentary sequence at Site U1307 allows the Pliocene sequence to be sampled using the APC system.

Two holes were cored at Site U1307, reaching a maximum depth of $162.6 \mathrm{mbsf}$. Two partial strokes of the APC required RCB drilling of two intervals in Hole U1307A that were difficult to penetrate using APC (50.5-52.5 and 73.7-77.7 mbsf). Average recovery was $102 \%$ for the cored intervals at Site U1307. Coring was terminated because of excessive heave when a passing storm system affected drilling operations.

The lower Pliocene to Pleistocene sedimentary succession at Site U1307, which is divided into three units, records variations in the input of terrigenous and biogenic components (mostly quartz, detrital carbonate, nannofossils, and foraminifers). Unit I (0$49.55 \mathrm{mcd}$ ) is composed of Quaternary mixtures of foraminifers, silty clay, and nannofossils (silty clay with foraminifers, foraminifer silty clay, and nannofossil silty clay). Minor lithologies include eight discrete foraminifer silty sand and sandy foraminifer ooze beds. Unit II (49.55-133.86 mcd) is composed mainly of Pleistocene to upper Pliocene silty clay with a minor biogenic component. Unit III (133.86$173.6 \mathrm{mcd}$ ) comprises upper to lower Pliocene silty clay, silty clay with nannofossils, and nannofossil silty clay. With the exception of the foraminifer sand beds, calcium carbonate content is low (mean = $3.8 \mathrm{wt} \%)$.

Calcareous, siliceous, and organic-walled microfossils are common to rare with moderate to poor preservation. A possible hiatus ( $\sim 0.25$ m.y. in duration) or condensed interval ( 1.21-1.45 Ma) is indicated by nannofossil biostratigraphy at $\sim 56-61 \mathrm{mcd}$. The dominant components of each microfossil group reflect subpolar to polar conditions during the Pleistocene. In the lower upper Pliocene (before 2.74 Ma), the nannofossil assemblage suggests warmer surface water conditions. Sarnthein et al. (2009) measured oxygen isotope data and SST proxies in the 2.7-3.5 Ma interval at Site U1307 and interpreted the results in terms of a cooling by $\sim 6^{\circ} \mathrm{C}$ and freshening by $\sim 2 \mathrm{psu}$ from 3.2 to $3.0 \mathrm{Ma}$, attributable to changes in the East Greenland Current, that they associate with a phase of closure of the Central American Seaway, thereby implicating this tectonic event in the onset of Northern Hemisphere Glaciation.

Paleomagnetic directional data yield an almost continuous sequence and permit unambiguous identification of the Brunhes, Matuyama, and Gauss Chrons. Within the Matuyama Chron, the Jaramillo, Olduvai, and Reunion Subchrons are clearly recognized. Within the Gauss, the Kaena and Mammoth Subchrons are also recognized, with the base of the section corresponding to the top of the Gilbert Chron.

With only two holes drilled, it was impossible to construct a complete spliced record for Site U1307. However, several long intervals of overlap between holes allowed segments to be correlated between holes (0-56.5, 76.4-104.7, and 104.7-146.2 mcd), which were then appended in the record. The mean sedimentation rate calculated using biostratigraphic and magnetostatigraphic datums is $4.8 \mathrm{~cm} / \mathrm{k} . \mathrm{y}$. Using only magnetostratigraphic datums, interval sedimentation rates vary between 2.7 and $7.6 \mathrm{~cm} / \mathrm{k} . \mathrm{y}$.

As for the other Eirik Drift sites, pore water geochemical profiles reflect the influence of organic matter remineralization reactions (see Ennyu and Malone). Pore water sulfate decreases linearly from seawater 
values to $\sim 1 \mathrm{mM}$ at 79 mbsf. The methane profile is atypical, decreasing from 200 ppmv near the sediment/ water interface to a low of $\sim 30 \mathrm{ppmv}$ at $54 \mathrm{mbsf}$ and increasing again below the sulfate reduction zone to a high of 26,000 ppmv. Calcium and strontium attain minimum values $(5.5 \mathrm{mM}$ and $76 \mu \mathrm{M}$, respectively) at the base of the sulfate reduction zone where alkalinity reaches a maximum $(10 \mathrm{mM})$, suggesting carbonate mineral precipitation.

Physical property records at Site U1307 document high-frequency changes in sediment composition. The variability in sediment composition recorded in magnetic susceptibility, NGR, and density likely reflect changes in paleoceanographic conditions in the overlying and surrounding water masses and ice sheets at a range of timescales. Site U1307 sediments are also characterized by an overall downcore increase in density (from 1.55 to $\sim 1.76 \mathrm{~g} / \mathrm{cm}^{3}$ ) and variable but generally decreasing porosity $(\sim 70 \%$ to $40 \%)$.

Site U1307 demonstrates that the Pliocene sediments of the Eirik Drift are located at penetration depths achievable with the APC. Apart from one possible hiatus (at 1.2-1.4 Ma) the sedimentary record at Site U1307 is apparently continuous with a mean sedimentation rate of $\sim 5 \mathrm{~cm} / \mathrm{k}$.y. The base of the recovered section correlates to the uppermost Gilbert Chron, indicating that the record extends to $\sim 3.6 \mathrm{Ma}$. The sediments from Site U1307 will provide information on the history of bottom and surface currents and of the Laurentide and Greenland ice sheets. Age control for seismic reflectors, provided by Site U1307 stratigraphy, will provide important constraints on the sedimentary architecture of the Eirik Drift.

\section{Site U1308}

Site U1308 is a reoccupation of Site 609, located in the core of the Ruddiman (1977) IRD belt (Fig. F1; Table T1). During DSDP Leg 94 (June-August, 1983), two principal holes (Hole 609A and Hole 609B) were drilled with the variable length piston coring (VLHPC) system and XCB. During that leg, two cores were collected from Hole 609A to recover the mudline, and seven XCB cores were collected from Hole 609C to recover the 123-190 mbsf interval. Samples from Site 609 have played a major role is driving some of the most exciting developments in paleoceanographic research during the last $20 \mathrm{y}$, such as the recognition and understanding of Heinrich layers, the recognition of the $1500 \mathrm{y}$ pacing in hematite-stained grains and Icelandic glass, and the correlation of ice-core $\delta^{18} \mathrm{O}$ to SST proxies (Broecker et al., 1992; Bond et al., 1992, 1999, 2001). The majority of the analyses from Site 609 have dealt with the record younger than MIS 6, partly because of the lack of a continuous pristine composite record. A primary objective at Site U1308, the reoccupation of Site 609 , was to recover a demonstrably complete composite record and hence considerably enhance the potential for Pliocene-Quaternary climatic records from this site.

The upper Miocene through Quaternary sedimentary succession at Site U1308, which is divided into two units, records variations in the input of terrigenous and biogenic sediments, primarily nannofossil ooze, nannofossil silty clay, and silty clay. Unit I (0196.85 mcd) comprises a Holocene to upper Pliocene sequence of interbedded biogenic and terrigenous sediments with dropstones. Subunit IIA (196.85$262.14 \mathrm{mcd}$ ) is upper Pliocene nannofossil ooze interbedded with terrigenous sediment-rich layers but at a lower frequency than Unit I. Subunit IIB (262.14-355.89 mcd) is entirely composed of lowermost upper Pliocene to uppermost Miocene nannofossil ooze.

Diverse assemblages of calcareous, siliceous, and organic-walled microfossils were recovered at Site U1308. Calcareous microfossils are abundant with good preservation in the upper $200 \mathrm{mcd}$, grading to moderate preservation below this depth (Sato et al.; Chiyonobu et al.). Siliceous microfossils are rare to common and moderately preserved above $\sim 255 \mathrm{mcd}$ (upper Pliocene-Pleistocene), with radiolarians locally abundant only in the middle part of the cored sequence. Siliceous microfossils are absent below $255 \mathrm{mcd}$. The concentration of terrestrial palynomorphs is low. Dinocysts are common to abundant in the upper $200 \mathrm{mcd}$. Microfossil floral changes observed at Site U1308 document the onset of Northern Hemisphere glaciation, as well as seasonal changes in bioproductivity and the location of hydrographic fronts.

Paleomagnetic directional data document an apparently continuous sequence of polarity transitions. Identification of the Brunhes, Matuyama, and Gauss Chrons are unambiguous (see Channell et al., 2008). The Gilbert Chron is tentatively recognized in the lower part of Hole U1308A. The Jaramillo, Cobb Mountain, Olduvai, Reunion, Kaena, and Mammoth Subchrons are also clearly identified.

Six holes were cored at Site U1308 to ensure complete recovery of the stratigraphic section to $247 \mathrm{mcd}$. The unusually large number of holes was required because of poor recovery and core disturbance caused by excessive heave and crushed core liners. One problematic interval between $\sim 186$ and $\sim 196$ mcd contains inclined bedding and sharp lithologic contacts that suggest a possible break in continuity 
of sedimentation. The mean linear sedimentation rate calculated using magnetostatigraphic datums is $\sim 8.3 \mathrm{~cm} / \mathrm{k}$.y. for the last $\sim 3.5 \mathrm{~m}$.y. Prior to that time the mean sedimentation rate was $\sim 3.3 \mathrm{~cm} / \mathrm{k}$.y. based on biostratigraphic markers.

Interstitial water sulfate decreases downhole to $9 \mathrm{mM}$, but complete sulfate reduction is not achieved within the cored interval. Unlike all other Expedition 303 sites, strontium increases with depth to a maximum of $1592 \mu \mathrm{M}$ at Site U1308. The nearly linear strontium increase and the corresponding increase in $\mathrm{Sr} / \mathrm{Ca}$ ratios indicates that recrystallization (not dissolution) of biogenic carbonate is occurring. Downhole decreases in magnesium and potassium and increase in calcium below 100 mbsf are consistent with the alteration of volcanic material and/or basement below the cored interval.

Physical property records at Site U1308 document long-term changes in sediment composition, which likely reflect fundamental changes in North Atlantic climate. The NGR and lightness $\left(\mathrm{L}^{*}\right)$ records from lithologic Unit I (0-197 mcd) show a strong glacialinterglacial variability. In Subunit IIA (197-262 mcd), magnetic susceptibility and NGR values decrease both in absolute value and variability and $L^{*}$ increases. NGR shows a fairly abrupt change in absolute values and variability at the Unit II/I boundary at $\sim 197 \mathrm{mcd}(\sim 2.74 \mathrm{Ma})$. In the white nannofossil ooze of lithologic Subunit IIB (262-356 mcd), magnetic susceptibility and NGR values are significantly lower and less variable than in Subunit IIA.

The six holes at Site U1308 have been pieced together to produce a complete composite section to $\sim 247 \mathrm{mcd}$. The base of the composite section correlates to the middle part of the Gauss Chron at $\sim 3.2 \mathrm{Ma}$. A discontinuous record of white upper Miocene nannofossil ooze was recovered below this level down to $356 \mathrm{mcd}$. The upper Pliocene to Quaternary composite section provides a means of studying the evolution of NADW, the extension of the Central Atlantic detrital layer (Heinrich-type) stratigraphy beyond the last glacial cycle, and the 1500 y cycle in the petrologic characteristics of IRD. The mean sedimentation rate for the composite section $(7.6 \mathrm{~cm} / \mathrm{k} . \mathrm{y}$. $)$ indicates that these studies can be carried out at moderately high resolution.

At Site U1308, a detailed benthic oxygen isotope record has been resolved for the upper $110 \mathrm{mcd}$, equivalent to the last 1.5 m.y. (Hodell et al., 2008). The age model was based on the optimal fit of the benthic oxygen isotope record to the oxygen isotope stack of Lisiecki and Raymo (2005), augmented by correlations to Core MD952042 (Shackleton et al., 2004) for the $35-60 \mathrm{ka}$ interval, and by ${ }^{14} \mathrm{C}$ ages in the 14-35 ka interval that were transferred from Site
609 using reflectance records (Hodell et al., 2008). The resulting sedimentation rate map indicates interval sedimentation rates in the range of 3.8$16.0 \mathrm{~cm} / \mathrm{k} . y$. , with minima in glacial MIS 10,12 , and 48 and the maximum in interglacial MIS 31. Although other interglacial stages, such as MIS 13 and 17 , have relatively high sedimentation rates, other prominent interglacial stages such as MIS 11 do not have particularly elevated sedimentation rates relative to neighboring glacial intervals.

Heinrich-type detrital layers at Site U1308 can be detected using magnetic susceptibility, GRA density measurements, $\delta^{18} \mathrm{O}$ of bulk carbonate, and $\mathrm{Ca} / \mathrm{Sr}$ ratios derived from XRF core scanning (Figs. F3, F4) (Hodell et al., 2008). The $\mathrm{Ca} / \mathrm{Sr}$ ratio provides a means of distinguishing detrital carbonate from biogenic carbonate (and hence detecting Heinrich-type detrital layers) because of the relatively high concentration of $\mathrm{Sr}$ in biogenic carbonate relative to detrital carbonate dominated by inorganic carbonate and dolomite. The $\delta^{18} \mathrm{O}$ of bulk carbonate is also a useful proxy for Heinrich-type detrital layers because of the different values of $\delta^{18} \mathrm{O}$ for (inorganic) detrital carbonate and foraminifer calcite (Hodell and Curtis, 2008). The Si/Sr ratio from XRF scanning was used to detect layers that are poor in biogenic carbonate (low $\mathrm{Sr}$ and $\mathrm{Ca}$ ) but relatively rich in detrital silicate minerals (Hodell et al., 2008). The $\mathrm{Si} / \mathrm{Sr}$ ratio mimics counts of the ratio of lithics to foraminifers from Site 609 (Bond et al., 1992) (Fig. F3).

The record of "Hudson Strait" Heinrich-type detrital layers, based on the $\mathrm{Ca} / \mathrm{Sr}$ ratio, has been placed in a precise chronostratigraphic framework based on benthic oxygen isotope data, indicating the existence of detrital carbonate-rich layers during glacial stages to MIS 16 (Hodell et al., 2008). Hudson-Straitderived Heinrich-type events, characterized by detrital carbonate, appear in MIS 8, 10, 12, and 16 but not apparently in MIS 6 or 14 (Fig. F4). At Site U1313 (see below), located at the southern edge of Ruddiman's IRD belt, Heinrich-type layers characterized by lithics with detrital carbonate (dolomite) appear in glacial MIS 10, 12, and 16 as well as at Terminations V and VII (Stein et al., 2009; Voelker et al., 2010).

The lead $(\mathrm{Pb})$ isochron method applied to detrital carbonate grains extracted from Heinrich-type detrital layers detected through the $\mathrm{Ca} / \mathrm{Sr}$ ratio yields Ordovician depositional/diagenetic ages consistent with a Hudson Strait (Laurentide) source (Nielsen and Hodell, submitted). Furthermore, the Heinrichtype detrital layers were clearly identified by a unique biomarker association of "petrogenic" compounds such as benzohopanes, D-ring monoaromatic 8,14-secohopanes, rearranged diasterenes, mono- and triaromatic steranes, and isorenieratene 
derivatives, as well as characteristic pristane $/ n-\mathrm{C}_{17}$ and pristane/phytane ratios (Hefter et al., 2007). This biomarker association provides circumstantial evidence for derivation from a relatively immature Paleozoic marine rock deposited under occasional photic zone anoxic conditions, which is today located on the Laurentide/Canadian shield (Rashid and Grosjean, 2006). Reinvestigation of available geologic and organic geochemical data narrowed this assumed source to an Ordovician oil shale close to Hudson Strait, which bears a striking resemblance in terms of biomarker distributions when compared to the specific association of compounds in Heinrichtype detrital events (Hefter et al., 2007).

Interestingly, MIS 6 (and MIS 14) differs from other glacial stages in the MIS 2-16 interval as being apparently devoid of Heinrich-type detrital layers. This observation is consistent with the rarity or absence of the radiolarian species Amphimelissa setosa during MIS 6, indicating relatively warm sea-surface conditions relative to other Brunhes-aged glacial stages (see K.R. Bjørklund et al., unpubl. data). In addition to the $\mathrm{Ca} / \mathrm{Sr}$ ratio, Heinrich-type detrital layers rich in dolomite can be effectively detected using a Fourier transform infrared spectrophotometer (Balsam et al., 2007), and this method has been put to use in the uppermost $29 \mathrm{~m}$ of the sediment recovered at Site U1308 (Ji et al., 2009).

Oxygen isotope $\left(\delta^{18} \mathrm{O}\right)$ values from detrital carbonate associated with Heinrich-type layers are $~ 9 \%$ lower than coexisting foraminifer calcite. Hodell and Curtis (2008) have shown that the $\delta^{18} \mathrm{O}$ of bulk carbonate at Sites U1308 and U1302/U1303 provides a means of detecting detrital carbonate associated with Heinrich-type layers. The $\delta^{18} \mathrm{O}$ of bulk carbonate can therefore be used to recognize Heinrich-type layers rich in detrital carbonate, and hence provide a clue to provenance. This observation has implications for oxygen isotope data from (planktonic) foraminifers within carbonate-rich detrital layers that may be "contaminated" by adhered detrital carbonate resulting in spuriously low $\delta^{18} \mathrm{O}$ values, previously interpreted as meltwater pulses (e.g., Hillaire-Marcel et al., 1994).

Benthic stable isotope data and lithic grain counts in the MIS G4 and 100 (2.5-2.6 Ma) interval at Site U1308, close to the Gauss/Matuyama boundary, indicate large amplitude suborbital variations in ice rafting at the onset of Northern Hemisphere Glaciation (NHG) (Bailey et al., 2010). As benthic $\delta^{18} \mathrm{O}$ maxima were $\sim 0.45 \%$ o lower in this interval than for the late Pleistocene, it was supposed that the benthic oxygen isotope "ice-volume threshold" at the onset of NHG, required to trigger ice sheet instability, was lower than for the late Pleistocene, implying differ- ences in ice sheet dynamics and morphology at the onset of NHG (Bailey et al., 2010).

Stratigraphic control at Site U1308 has been enhanced by a RPI record that has been calibrated using benthic oxygen isotope data for the last $1.5 \mathrm{~m}$.y. (Fig. F5) (Channell et al., 2008). The Site U1308 RPI and $\delta^{18} \mathrm{O}$ records have higher resolution and fidelity than most coupled RPI $/ \delta^{18} \mathrm{O}$ records. They are therefore used as the templates for RPI and $\delta^{18} \mathrm{O}$ stacks for the last 1.5 m.y., through correlation to Site U1308 of 12 globally distributed (but mainly North Atlantic) sites that have yielded both RPI and $\delta^{18} \mathrm{O}$ data (Channell et al., 2009b). The coupled correlations of isotope and RPI data are accomplished using the Match algorithm (Lisiecki and Lisiecki, 2002). The simultaneous match reduces the degree of freedom associated with correlations using RPI or oxygen isotope records alone. The overall compatibility of RPI and oxygen isotopes indicates a dominant global component in both signals. The so-called PISO-1500 stacks represent a powerful new stratigraphic tool that can be used to correlate among marine sediment records and link them to polar ice cores through variations in cosmogenic nuclide production. Scaling the RPI stack to values for virtual axial dipole moment (VADM) indicate maxima at $\sim 15 \times 10^{22} \mathrm{Am}^{2}$ and minima that imply a threshold of $\sim 2.5 \times 10^{22} \mathrm{Am}^{2}$, below which values are associated with either polarity reversals or magnetic excursions. The resulting $\mathrm{RPI} /$ isotope templates are part of an overall goal of enhancing stratigraphic resolution by combined use of oxygen isotope and RPI.

\section{Site U1312}

Site U1312 is a reoccupation of Site 608 drilled in 1983 with a total penetration of $530 \mathrm{mbsf}$ and reaching basaltic basement (capped by middle Eocene sediments) at 515 mbsf. The principal objective at Site U1312 was to recover a complete composite section of a classic upper Miocene section that became a reference section for Miocene stratigraphy through stable isotope, magnetic, and paleontological studies (Clement and Robinson, 1987; Miller et al., 1991; Gartner, 1992). Recently acquired paleomagnetic data derived from a resampling of Site 608 cores (Krijgsman and Kent, 2004) attests to the fidelity of the paleomagnetic record at this site, even after $25 \mathrm{y}$ of core storage. This new sampling extended from polarity Chron $3 \mathrm{Br}$ to $5 \mathrm{An}$ and indicated a mean sedimentation rate in this part of the late Miocene of $2.5 \mathrm{~cm} / \mathrm{k} . \mathrm{y}$. The reoccupation of Site 608 held the promise of recovery of a complete composite section, particularly for the upper Miocene and lower Pliocene. At the time of original drilling (1983) during 
Leg 94, composite section construction during drilling was not a viable option.

Two holes were drilled at Site U1312, however, the quality of the recovered core was very poor compared to that recovered 25 y earlier during Leg 94 . Both Holes U1312A and U1312B were affected by drilling disturbance and "flow-in" such that a composite record could not be constructed for this site. The high level of drilling disturbance was attributed to excessive ship heave $(>5 \mathrm{~m})$, and the site was finally abandoned as weather conditions worsened. The shipboard magnetic stratigraphy was only interpretable in one hole (U1312B), and in this hole only back into the Matuyama Chron, to 2 Ma. Shorebased magnetic studies have improved the fidelity of the magnetic record over the last $\sim 2$ m.y., and RPI proxies in this interval have been correlated to other records from the North Atlantic (Kanamatsu et al.).

In view of the high-quality magnetic data acquired from Site 608 (Clement and Robinson, 1987; Krijgsman and Kent, 2004), the lack of interpretable magnetic stratigraphy prior to $\sim 2$ Ma for the section recovered during Expedition 303/306 must be attributable to core quality, although this disturbance is not always visually apparent according to shipboard core descriptions. The lack of a complete composite section and magnetic stratigraphy beyond the last $\sim 2$ m.y. will inhibit further work on cores recovered from Site U1312.

\section{Site U1313}

Site U1313 is a reoccupation of Site 607, drilled in 1983 during Leg 94. The rationale for reoccupying this site is essentially the same as that for Site 609 (Site U1308). Together, Sites 609 and 607 constitute benchmark sites for the long-term (millions of years) surface and deep ocean climate records from the subpolar North Atlantic (Ruddiman et al., 1986, 1989; Raymo et al., 1989). Leg 94 drilling of this site preceded the shipboard capability for construction of composite sections and pass-through magnetometers for continuous measurement of magnetic parameters, and the objective was to recover a complete composite section and generate a high-resolution stratigraphic record.

Four holes were drilled at Site U1313, reaching a maximum depth of 308 mbsf and providing the means of constructing an apparently complete composite section back into the late Miocene ( $6 \mathrm{Ma})$ at mean sedimentation rates of $\sim 5 \mathrm{~cm} / \mathrm{k}$.y. for the PlioceneQuaternary and perhaps as high as $\sim 13-14 \mathrm{~cm} / \mathrm{k} . \mathrm{y}$. for the upper Miocene. The Holocene to upper Pliocene sediments are composed of nannofossil ooze and silty clay nannofossil ooze. Below these sedi- ments, the Pliocene to upper Miocene sediments are homogeneous nannofossil oozes with high (>90 wt $\%$ ) carbonate values.

Shipboard correlation among holes was unambiguous in the upper $168 \mathrm{~m}$, based largely on sediment color/reflectance data that mimic the marine oxygen isotope curve (Stein et al., 2006). The homogeneity of the nannofossil oozes below this level resulted in less secure hole-to-hole correlations. The shipboard magnetic stratigraphy is interpretable through most of the Gauss Chron to 150 mbsf. Below this depth, the magnetic stratigraphy is hampered by low magnetization intensities, although postcruise U-channel studies have helped to resolve the magnetic stratigraphy through the Gilbert Chron and into the late Miocene (Evans et al., 2006).

Diatom flora are present within the upper $\sim 70 \mathrm{mbsf}$ (Pliocene-Pleistocene interval). Calcareous nannofossils are abundant and moderately well preserved to well preserved, and a complete succession of nannofossil datums has been determined for the upper 158 mbsf, to $\sim 3 \mathrm{Ma}$ (Hagino and Kulhanek). Sierro et al. studied Pliocene-Pleistocene planktonic foraminifer events at this site and assigned ages using the correlation of sediment color/reflectance data to an oxygen isotope reference curve. These ages have been compared with the same datums in the Mediterranean where calibration was previously achieved through astrochronology. An oxygen isotope stratigraphy has been generated from planktonic and benthic foraminifers for part of the record, specifically the MIS 10-16 interval (Voelker et al., 2009, 2010), providing both chronological control and information about surface and deep water conditions. Planktonic and benthic oxygen isotope data, lithic fragment, and physical grain size data at Site U1313 indicate that major Heinrich-type ice-rafting events were associated with Terminations $\mathrm{V}$ and VII and with MIS 10 and 12 (Voelker et al., 2010). Lower benthic $\delta^{13} \mathrm{C}$ values indicate weakened meridonial overturning circulation (MOC) and the presence of Antarctic Bottom Water during all glacial periods in this interval (MIS 10-16) with strong MOC during all interglacials.

First results from biomarker analyses, performed shipboard, indicate that alkenone-derived SSTs show variability from $\sim 13^{\circ}$ to $19^{\circ} \mathrm{C}$ during the Pleistocene (Stein et al., 2006). A few data points from the late Pliocene interval display SST values of $\sim 17^{\circ}$ to $22^{\circ} \mathrm{C}$. With new shore-based data representing the 320 $640 \mathrm{ka}$ (MIS 9-16) interval, Stein et al. (2009) are able to compare SST variability, surface water productivity, and IRD deposition during the more severe glacials (MIS 16, 12, 10) with the weaker glacial MIS 14 , and, on the other hand, the extreme interglacials 
MIS 11 and the less extreme interglacial MIS 15 and 13. Alkenone-based SST reached an absolute maximum of $\sim 19^{\circ} \mathrm{C}$ during MIS 11.3 and absolute minima of $<10^{\circ} \mathrm{C}$ during MIS 12 and 10 . Within MIS 11, prominent cooling events (MIS 11.22 and 11.24) occurred. The absolute SST minima, recorded directly before and after the glacial maxima MIS 12.2 and 10.2, are related to Heinrich-like meltwater pulses, as supported by the coincidence of SST minima with maxima in $\mathrm{C}_{37: 4}$ alkenones and dolomite (Fig. F6). Based on these data, ice sheet disintegration and subsequent surges and outbursts of icebergs and meltwater discharge appear to have been triggered by increased insolation forcing at high northern latitudes (Stein et al., 2009).

Ferretti et al. (2010) documented the MIS 20-23 interval at Site U1313 using $\delta^{18} \mathrm{O}$ from both benthic and planktonic foraminifers. MIS 21 can be broken into four interstadial periods that can be correlated to other North Atlantic isotopic records from Site U1308 (Hodell et al., 2008), Site 983 (Channell and Kleiven, 2000), and ODP Site 1063 (Ferretti et al., 2005). These variations in MIS 21 are evident in both the planktonic and benthic isotope records, although they are more muted in the benthic records. Ferretti et al. (2010) matched these variations to insolation variations at the Equator and suggested a forcing mechanism related to low-latitude precession variations and advection to high latitudes by tropical convective processes.

\section{Site U1314}

The objective of drilling Site U1314 was to obtain a deepwater record of past oceanographic conditions to compare to deepwater Site U1304 from the southern Gardar Drift and the intermediate depth site on the northern part of the Gardar Drift sampled during Leg 162 at Site 983. Site U1314 is located north of Site U1304 in the southern Gardar Drift (Fig. F1), at a water depth of 2820 meters below sea level (mbsl), and just north of the Ruddiman (1977) IRD belt. As at Site U1304, the stratigraphic record at Site U1314 will allow high-resolution monitoring of NADW variability and ice sheet instability over the last $\sim 3$ m.y.

Three holes were drilled at Site U1314 using the APC system to a maximum depth of 280 mbsf. Hole-tohole stratigraphic correlation was straightforward to 281 mcd (mid-Gauss Chron; 3 Ma) using magnetic susceptibility and NGR, apart from one tenuous tie between Holes U1314B and U1314C at $25.90 \mathrm{mcd}$. The sedimentary sequence is composed of mainly greenish gray nannofossil oozes with clays, with abundant siliceous and calcareous microfossils. Cal- cium carbonate content ranges from $<10$ to $>70 \mathrm{wt} \%$, with an average of $34 \mathrm{wt} \%$, and the variations are in step with nannofossil abundance. A variability of 20-30 wt \% in $\mathrm{CaCO}_{3}$ around the mean persists throughout the entire section. Variations in sediment color/reflectance follow $\mathrm{CaCO}_{3}$ variations but do not mimic an oxygen isotope record. Biogenic silica abundances, dominated by diatoms, reach $25 \%$ of visible grains in shipboard smear slides. Diatomrich laminae, dominated by Thalassiothrix, recur periodically throughout the stratigraphic sequence. J. Grützner and S.M. Higgins (unpubl. data) have derived an orbital age model for Site U1314 by correlating sediment physical properties from this site with equivalent data from Site 983. Mean sedimentation rates are estimated at $\sim 7-8 \mathrm{~cm} / \mathrm{k} . \mathrm{y}$. in the Pleistocene and $11-12 \mathrm{~cm} / \mathrm{k} . \mathrm{y}$. in the late Pliocene. The magnetic polarity stratigraphy is unambiguous to the Gauss Chron at $\sim 3 \mathrm{Ma}$, and the fidelity of the magnetic record is exemplified by detailed study of the GaussMatuyama polarity transition (Ohno et al., 2008). The longer polarity subchrons (Jaramillo and Olduvai) and brief subchrons such as the Cobb Mountain and Réunion are recorded.

Rich nannofossil (Hagino and Kulhanek), radiolarian, and planktonic foraminifer and diatom (see the "Site U1314" chapter) assemblages occur throughout the sedimentary sequence and are suitable for reconstruction of SSTs for the late Pliocene-Pleistocene interval. Benthic foraminifers (see the "Site U1314" chapter) and ostracodes (Alvarez Zarikian) are diverse and generally well preserved. The good preservation of benthic microfossils makes this site suitable for developing a benthic isotopic record and reconstructing deep-sea environmental conditions. Alvarez Zarikian et al. (2009) studied the ostracode assemblage at this site over the past $170 \mathrm{k} . \mathrm{y}$. and showed that changes in ostracode abundance, diversity, and assemblage composition are apparently linked to changes in deep sea water masses and glacial-interglacial cyclicity. The ostracod assemblage found during glacial stages comprises shelf and intermediate water Arctic/ subarctic species, and abyssal North Atlantic species, which possibly reflect temporal shifts in the influence of high-nutrient southern source waters (e.g., Antarctic Bottom Water) and low-nutrient waters (e.g., Glacial North Atlantic Intermediate Water) at these times. In contrast, interglacial ostracode assemblages are characterized by deep cosmopolitan species that are known to be associated with NADW and increased food supply to the sediments (Dingle and Lord, 1990; Cronin et al., 1999; Didié and Bauch, 2000). Glacial and interglacial ostracode assemblages found at Site U1314 show a strong affinity to those found on the Rockall Plateau (Didié and Bauch, 2000) and the mid-ocean ridge in the North Atlantic 
(Cronin et al., 1999), but species diversity is higher during the last two glacial intervals at Site U1314. Initial results by Sorrell and Judge (2007) and Alvarez Zarikian et al. (2009) have shown that sediments at Site U1314 contain a record of ice-rafted debris that can be used for monitoring ice sheet instability and reconstructing the glacial climate history of the North Atlantic Ocean.

\section{Site U1315}

ODP Site 642 (Site U1315) is located on the Vøring Plateau in a water depth of $\sim 1280$ mbsl. The primary objective at this site is to document the bottom water temperature and salinity variations with instrumentation that sits in the water column attached to an elevated reentry cone. Hole U1315A was drilled to $179 \mathrm{mbsf}$ and cased. The installed borehole observatory consists of a circulation obviation retrofit kit (CORK) to seal the borehole from the overlying ocean and instruments to monitor and document subbottom temperature variations. The instrumentation in Hole U1315A includes two pressure cases and a thermistor string. This configuration allows highprecision temperature measurements as a function of both depth and time. By analyzing subbottom temperature perturbations we expect to reconstruct, for the first time, a temperature record of bottom water during at least the last $100 \mathrm{y}$ (i.e., going back in time far beyond the directly measured temperature records available up to now). This record will contribute significantly to the ongoing discussion about causes and consequences of oceanographic and climatic changes observed in the North Atlantic over the last few decades. After setting the CORK in the newly drilled Hole U1315A (Harris et al., 2006), temperature measurements were made in Hole 642E to compare with those acquired $20 \mathrm{y}$ ago when the hole was drilled (see Eldholm et al., 1987). The comparison indicates fluid flowing from the basement, up the hole, and into the ocean at an estimated rate of 6-11 $\mathrm{m} / \mathrm{h}$ and yields an estimated permeability of $10^{-13} \mathrm{~m}^{2}$, reflecting relatively impermeable sediments overlying a relatively permeable basement (Harris and Higgins, 2008).

\section{Conclusions}

The overall objective of Expedition 303/306 is to generate high-resolution records of late MioceneQuaternary North Atlantic environmental change that can be placed in a high-resolution stratigraphic framework based on oxygen isotope and RPI data.

Apart from Site U1312, where coring disturbance attributed to severe weather conditions contributed to poor preservation of the record, paleomagnetic records from Expedition 303/306 sites are of high fidelity. In general, polarity chrons are well defined in shipboard data. Two postcruise studies of the details of polarity transitions attest to the quality of the magnetic records (Ohno et al., 2008; Mazaud et al., 2009). Isotope records are still in development at most Expedition 303/306 sites, although a coupled isotope/RPI record has been published for Site U1308 for the last 1.5 m.y. (Hodell et al., 2008; Channell et al., 2008) and this stratigraphy has been augmented by detailed nannofossil stratigraphy at this site (Sato et al.; Chiyonobu et al.). The benthic isotope and RPI records at Site U1308 over the last 1.5 m.y. have high resolution and fidelity and provide the reference records for coupled RPI/isotope stacks generated by tandem correlation of isotope and RPI data from 13 globally distributed records (Channell et al., $2009 \mathrm{~b}$ ). The tandem correlations use the Match protocol (Lisiecki and Lisiecki, 2002) that allows repeatable correlations using penalty functions that can be set to inhibit abrupt sedimentation rate changes within the records. This is a first step toward generating a template for stratigraphic correlation at a resolution not obtainable from oxygen isotopes alone. This development is important for the study of millennial-scale environmental change because the lack of tools for stratigraphic correlation, at an appropriate resolution, is presently a severe impediment to the study of phenomena associated with short-term "abrupt" climate change.

The detrital layer stratigraphy at Site U1308 has been resolved using density, magnetic susceptibility and $\mathrm{XRF}$ scanning, specifically the $\mathrm{Ca} / \mathrm{Sr}$ ratio, which is a valuable proxy for Hudson Strait-derived (Heinrichtype) detrital layers because of the low $\mathrm{Sr}$ content of inorganic (detrital) versus biogenic carbonate (Hodell et al., 2008). In addition, the distinctively lower $\delta^{18} \mathrm{O}$ values for detrital carbonate, relative to foraminifer calcite, means that bulk carbonate $\delta^{18} \mathrm{O}$ provides an additional means of recognizing detrital events (Hodell and Curtis, 2008). Low $\delta^{18} \mathrm{O}$ values from planktonic foraminifer tests contaminated by adhered detrital carbonate may mimic meltwater events. Hudson Strait-derived Heinrich events, characterized by detrital carbonate, appear in MIS 8, 10, 12 , and 16 but not, apparently, in MIS 6 or 14 (Hodell et al., 2008).

At Site U1313, Heinrich-type layers characterized by lithics with detrital carbonate occurred in glacial MIS 10,12 , and 16 as well as at Terminations V and VII (Stein et al., 2009; Voelker et al., 2010). High-resolution isotopic, alkenone, and XRD studies at Site U1313 in the 320-640 ka (MIS 9-16) interval have allowed detailed comparison of SST variability, surface water 
productivity, and IRD deposition in the central midlatitude North Atlantic (Stein et al., 2009; Voelker et al., 2010). Peaks in dolomite and feldspars and associated maxima in land-plant derived $n$-alkanes are interpreted as indicators of Heinrich-like events related to instability of the LIS, especially during early and late stages of glacial intervals (Stein et al., 2009).

Hudson Strait-derived Heinrich-type detrital layers first appear in the sedimentary records at Sites U1308 and U1313 in MIS 16, approximately coincident with the end of the mid-Pleistocene climate transition between the so-called 41 and 100 k.y. worlds. Although iceberg survivability may play a role in the apparent onset of this IRD record, it is more likely that ice volume and glacial stage duration surpassed critical thresholds at that time that activated LIS instability (Hodell et al., 2008). Benthic $\delta^{13} \mathrm{C}$ variations at Site U1308 support a link between iceberg discharge and weakening of thermohaline circulation.

Planktonic and benthic microfossils at Site U1314 have yielded valuable proxies for surface (radiolarian and calcareous nannofossils) and deep (ostracodes) water conditions in the North Atlantic. Radiolarian assemblages indicate warm SSTs during MIS 6 relative to other Brunhes glacial stages (K.R. Bjørklund et al., unpubl. data), whereas ostracode assemblages and species diversity can be associated with changes in deep ocean circulation and climate variability (Alvarez Zarikian et al., 2009).

The results from Sites U1308, U1313, and U1314 are a foretaste of what will be forthcoming from the group of sites occupied during Expedition 303/306. The preliminary data indicate that all sites have the attributes to provide records of North Atlantic environmental change that can be placed in a chronological framework based on oxygen isotope data and RPI.

\section{Acknowledgments}

We wish to thank the crew of the R/V JOIDES Resolution, including Captains Alex Simpson and Pete Mowat, Drilling Superintendents Wayne Malone and Tim McCown, and Operations Superintendents Ron Grout and Mike Storms, for their outstanding efforts to make IODP Expedition 303/306 a successful experience from both scientific and personal perspectives. Mitchell Malone played a very critical role in the organization of Expedition 303/306 and his efficiency and good humor in sometimes difficult circumstances were much appreciated. He also gave us the benefit of his experience and expertise as Staff Scientist on Expedition 303. Greg Mountain lent his help to the acquisition and organization of site survey data during and after Cruise KN166-14 of the R/V Knorr, and Bruce Malfait at the National Science Foundation facilitated cruise operations. David Piper provided site survey data for Site U1302/U1303. The personnel of the IODP core repository in Bremen (particularly Walter Hale and Alex Wuelbers) are thanked for their expert coordination of core handling, storage, and shore-based sampling. The IODP staff at College Station is thanked for coordination of shipboard operations, sampling strategy, data storage, and manuscript editing.

\section{References}

Alvarez Zarikian, C.A., Stepanova, A.Y., and Grützner, J., 2009. Glacial-interglacial variability in deep sea ostracod assemblage composition at IODP Site U1314 in the subpolar North Atlantic. Mar. Geol., 258(1-4):69-87. doi:10.1016/j.margeo.2008.11.009

Bailey, I., Bolton, C.T., DeConto, R.M., Pollard, D., Schiebel, R., and Wilson, P.A., 2010. A low threshold for North Atlantic ice rafting from "low-slung slippery" late Pliocene ice sheets. Paleoceanography, 25(1):PA1212. doi:10.1029/2009PA001736

Balsam, W., Damuth, J.E., and Deaton, B., 2007. Marine sediment components: identification and dispersal assessed by diffuse reflectance spectrophotometry. Int. J. Environ. Health, 1(3):403-426. doi:10.1504/ IJENVH.2007.017869

Bassinot, F.C., Labeyrie, L.D., Vincent, E., Quidelleur, X., Shackleton, N.J., and Lancelot, Y., 1994. The astronomical theory of climate and the age of the Brunhes-Matuyama magnetic reversal. Earth Planet. Sci. Lett., 126(13):91-108. doi:10.1016/0012-821X(94)90244-5

Bodén, P., and Backman, J., 1996. A laminated sediment sequence from northern North Atlantic Ocean and its climatic record. Geology, 24(6):507-510. doi:10.1130/ 0091-7613(1996)024<0507:ALSSFT>2.3.CO;2

Bond, G., Heinrich, H., Broecker, W., Labeyrie, L., McManus, J., Andrews, J., Huon, S., Jantschik, R., Clasen, S., Simet, C., Tedesco, K., Klas, M., Bonani, G., and Ivy, S., 1992. Evidence for massive discharges of icebergs into the North Atlantic Ocean during the last glacial period. Nature (London, U. K.), 360(6401):245-249. doi:10.1038/360245a0

Bond, G., Kromer, B., Beer, J., Muscheler, R., Evans, M.N., Showers, W., Hoffmann, S., Lotti-Bond, R., Hajdas, I., and Bonani, G., 2001. Persistent solar influence on North Atlantic climate during the Holocene. Science, 294(5549):2130-2136. doi:10.1126/science.1065680

Bond, G.C., and Lotti, R., 1995. Iceberg discharges into the North Atlantic on millennial time scales during the last glaciation. Science, 276(5200):1005-1010. doi:10.1126/ science.267.5200.1005

Bond, G.C., Showers, W., Elliot, M., Evans, M., Lotti, R., Hajdas, I., Bonani, G., and Johnson, S., 1999. The North Atlantic's 1-2 kyr climate rhythm: relation to Heinrich Events, Dansgaard/Oeschger cycles, and the Little Ice Age. In Clark, P.U., Webb, R.S., and Keigwin, L.D. (Eds.), 
Mechanisms of Global Climate Change at Millennial Time Scales. Geophys. Monogr., 112:35-58.

Broecker, W., Bond, G., Klas, M., Clark, E., and McManus, J., 1992. Origin of the northern Atlantic's Heinrich Events. Clim. Dyn., 6:(3-4)265-273. doi:10.1007/ BF00193540

Channell, J.E., Hodell, D.A., Romero, O.E., Hillaire-Marcel, C., de Vernal, A., Stoner, J.S., and Mazaud, A., 2009a. Testing North Atlantic relative paleointensity correlations for the Brunhes Chron with oxygen isotope data and markers for (Heinrich-type) detrital layers. Eos, Trans. Am. Geophys. Union, 90(52)(Suppl.):GP32A-06. (Abstract) http://www.agu.org/meetings/fm09/ waisfm09.html

Channell, J.E.T., Hodell, D.A., Xuan, C., Mazaud, A., and Stoner, J.S., 2008. Age calibrated relative paleointensity for the last 1.5 Myr at IODP Site U1308 (North Atlantic). Earth Planet Sci. Lett., 274(1-2):59-71. doi:10.1016/ j.epsl.2008.07.005

Channell, J.E.T., and Kleiven, H.F., 2000. Geomagnetic palaeointensities and astrochronological ages for the Matuyama-Brunhes boundary and the boundaries of the Jaramillo Subchron: palaeomagnetic and oxygen isotope records from ODP Site 983. Philos. Trans. R. Soc. London, A, 358(1768):1027-1047. doi:10.1098/ rsta.2000.0572

Channell, J.E.T., Sato, T., Kanamatsu, T., Stein, R., Malone, M., Alvarez-Zarikian, C., and the IODP Expeditions 303 and 306 Scientists, 2006. IODP Expeditions 303 and 306 monitor Miocene-Quaternary climate in the North Atlantic. Sci. Drill., 2:4-10. doi:10.2204/ iodp.sd.2.01.2006

Channell, J.E.T., Xuan, C., and Hodell, D.A., 2009b. Stacking paleointensity and oxygen isotope data for the last 1.5 Myr (PISO-1500). Earth Planet. Sci. Lett., 283(14):14-23. doi:10.1016/j.epsl.2009.03.012

Clement, B.M., and Robinson, F., 1987. The magnetostratigraphy of Leg 94 sediments. In Ruddiman, W.F., Kidd, R.B., Thomas, E., et al., Init. Repts. DSDP, 94 (Pt. 2): Washington (U.S. Govt. Printing Office), 635-650. doi:10.2973/dsdp.proc.94.112.1987

Cronin, T.M., DeMartino, D.M., Dwyer, G.S., and Rodriguez-Lazaro, J., 1999. Deep-sea ostracode species diversity: response to late Quaternary climate change. Mar. Micropaleontol., 37(3-4): 231-249. doi:10.1016/S03778398(99)00026-2

Didié, C., and Bauch, H.A., 2000. Species composition and glacial-interglacial variations in the ostracode fauna of the northeast Atlantic during the past 200,000 years. Mar. Micropaleontol., 40(1-2):105-129. doi:10.1016/ S0377-8398(00)00034-7

Dingle, R.V., and Lord, A.R., 1990. Benthic ostracods and deep water-masses in the Atlantic Ocean. Palaeogeogr., Palaeoclimatol., Palaeoecol., 80(3-4):213-235. doi:10.1016/0031-0182(90)90133-R

Eldholm, O., Thiede, J., and Taylor, E., 1987. Evolution of the Norwegian continental margin: background and objectives. In Eldholm, O., Thiede, J., Taylor, E., et al., Proc. ODP, Init. Repts., 104: College Station, TX (Ocean
Drilling Program), 5-25. doi:10.2973/

odp.proc.ir.104.101.1987

Evans, H.F., Acton, G.D., Guyodo, Y., Channell, J., Ohno, M., and Kanamatsu, T., 2006. Magnetic stratigraphy and relative paleointensity from IODP Site U1313 from 2.4$6 \mathrm{Ma}$. Eos, Trans. Am. Geophys. Union,

87(52)(Suppl.):GP13A-07. (Abstract)

Ferretti, P., Crowhurst, S.J., Hall, M.A., and Cacho, I., 2010. North Atlantic millennial-scale climate variability 910 to $790 \mathrm{ka}$ and the role of the equatorial insolation forcong. Earth Planet. Sci. Lett., 293(12):28-41. doi:10.1016/j.epsl.2010.02.016

Ferretti, P., Shackleton, N.J., Rio, D., and Hall, M.A., 2005. Early-middle Pleistocene deep circulation in the western subtropical Atlantic: southern hemisphere modulation of the North Atlantic Ocean. In Head, M.J., and Gibbard, P.L. (Eds.), Early-Middle Pleistocene Transitions: The Land-Ocean Evidence. Geol. Soc. Spec. Publ., 247:131145. doi:10.1144/GSL.SP.2005.247.01.07

Gartner, S., 1992. Miocene nannofossil chronology in the North Atlantic, DSDP Site 608. Mar. Micropaleontol., 18(4):307-331. doi:10.1016/0377-8398(92)90045-L

Harris, R.N., and Higgins, S.M., 2008. A permeability estimate in $56 \mathrm{Ma}$ crust at ODP Hole 642E, Vøring Plateau Norwegian Sea. Earth Planet. Sci. Lett., 267(1-2):378385. doi:10.1016/j.epsl.2007.11.055

Harris, R.N., and the IODP Expedition 306 Scientists, 2006. Borehole observatory installations on IODP Expedition 306 reconstruct bottom-water temperature changes in the Norwegian Sea. Sci. Drill., 2:28-31. doi:10.2204/ iodp.sd.2.03.2006

Hefter, J., Stein, R., and Sinninghe Damsté, J.S., 2007. The biomarker inventory, trace, and source of Heinrich Events and Heinrich-type layers (MIS 8-16) in the North Atlantic. Eos, Trans. Am. Geophys. Union, 88(52)(Suppl.):PP41C-0689. (Abstract) http:// www.agu.org/meetings/fm07/waisfm07.html

Hillaire-Marcel, C., de Vernal, A., Bilodeau, G., and Wu, G., 1994. Isotope stratigraphy, sedimentation rates, deep circulation, and carbonate events in the Labrador Sea during the last $200 \mathrm{ka}$. Can. J. Earth Sci., 31(1):63-89. doi:10.1139/e94-007

Hiscott, R.N., Aksu, A.E., Mudie, P.J., and Parsons, D.F., 2001. A 340,000 year record of ice rafting, paleoclimatic fluctuations, and shelf-crossing glacial advances in the southwestern Labrador Sea. Global Planet. Change, 28(14):227-240. doi:10.1016/S0921-8181(00)00075-8

Hodell, D.A., Channell, J.E.T, Curtis, J.H., Romero, O.E., and Rohl, U., 2008. Onset of "Hudson Strait" Heinrich Events in the eastern North Atlantic at the end of the middle Pleistocene transition ( 640 ka)? Paleoceanography, 23(4):PA4218. doi:10.1029/2008PA001591

Hodell, D.A., and Curtis, J.H., 2008. Oxygen and carbon isotopes of detrital carbonate in North Atlantic Heinrich Events. Mar. Geol., 256(1-4):30-35. doi:10.1016/j.margeo.2008.09.010

Hodell, D.A., Minth, E.K., Curtis, J.H., McCave, I.N., Hall, I.R., Channell, J.E.T., and Xuan, C., 2009. Surface and deep water hydrography on Gardar Drift (Iceland Basin) 
during the last interglacial period. Earth Planet. Sci. Lett. 288(1-2):10-19. doi:10.1016/j.epsl.2009.08.040

Ji, J., Ge, Y., Balsam, W., Damuth, J.E., and Chen, J., 2009. Rapid identification of dolomite using a Fourier Transform Infrared Spectrophotometer (FTIR): a fast method for identifying Heinrich Events in IODP Site U1308. Mar. Geol., 258(1-4):60-68. doi:10.1016/j.margeo.2008.11.007

Krijgsman, W., and Kent, D.V., 2004. Non-uniform occurrence of short-term polarity fluctuations in the geomagnetic field? New results from middle to late Miocene sediments of the North Atlantic (DSDP Site 608). In Channell, J.E.T., Kent, D.V., Lowrie, W., and Meert, J.G. (Eds.), Timescales of the Paleomagnetic Field. Geophys. Monogr. 145:161-174.

Lisiecki, L.E., and Lisiecki, P.A., 2002. Application of dynamic programming to the correlation of paleoclimate records. Paleoceanography, 17(4):1049. doi:10.1029/2001PA000733

Lisiecki, L.E., and Raymo, M.E., 2005. A Pliocene-Pleistocene stack of 57 globally distributed benthic $\delta^{18} \mathrm{O}$ records. Paleoceanography, 20(1):PA1003. doi:10.1029/ 2004PA001071

Locarnini, R.A., Mishonov, A.V., Antonov, J.I., Boyer, T.P., and Garcia, H.E., 2006. World Ocean Atlas 2005, Volume 1: Temperature. In Levitus, S. (Ed.), NOAA Atlas NESDIS 61: Washington, DC (U.S. Govt. Printing Office).

Mazaud, A., Channell, J.E.T., Xuan, C., and Stoner, J.S., 2009. Upper and lower Jaramillo polarity transitions recorded in IODP Expedition 303 North Atlantic sediments: implications for transitional field geometry. Phys. Earth Planet. Inter., 172(3-4):131-140. doi:10.1016/j.pepi.2008.08.012

Miller, K.G., Feigenson, M.D., Wright, J.D., and Clement, B.M., 1991. Miocene isotope reference section, Deep Sea Drilling Project Site 608: an evaluation of isotope and biostratigraphic resolution. Paleoceanography, 6(1):3352. doi:10.1029/90PA01941

Ohno, M., Murakami, F., Komatsu, F., Guyodo, Y., Acton, G., Kanamatsu, T., Evans, H.F., and Nanayama, F., 2008. Paleomagnetic directions of the Gauss-Matuyama polarity transition recorded in drift sediments (IODP Site U1314) in the North Atlantic. Earth, Planets Space, 60:e13-e16. http://www.terrapub.co.jp/journals/ EPS/pdf/2008e/6009e013.pdf

Rashid, H., and Grosjean, E., 2006. Detecting the source of Heinrich Layers: an organic geochemical study. Paleoceanography, 21(3):PA3041. doi:10.1029/ 2005PA001240

Raymo, M.E., Ruddiman, W.F., Backman, J., Clement, B.M., and Martinson, D.G., 1989. Late Pliocene variation in Northern Hemisphere ice sheets and North Atlantic deep water circulation. Paleoceanography, 4(4):413-446. doi:10.1029/PA004i004p00413

Ruddiman, W.F., 1977. Late Quaternary deposition of icerafted sand in the subpolar North Atlantic (lat $40^{\circ} \mathrm{N}$ to $65^{\circ}$ N). Geol. Soc. Am. Bull., 88(12):1813-1827. doi:10.1130/0016-

7606(1977)88<1813:LQDOIS >2.0.CO;2
Ruddiman, W.F., Raymo, M., and McIntyre, A., 1986. Matuyama 41,000-year cycles: North Atlantic Ocean and Northern Hemisphere ice sheets. Earth Planet. Sci. Lett., 80(1-2):117-129. doi:10.1016/0012821X(86)90024-5

Ruddiman, W.F., Raymo, M.E., Martinson, D.G., Clement, B.M., and Backman, J., 1989. Pleistocene evolution: Northern Hemisphere ice sheets and North Atlantic Ocean. Paleoceanography, 4(4):353-412. doi:10.1029/ PA004i004p00353

Sarnthein, M., Bartoli, G., Prange, M., Schmittner, A., Schneider, B., Weinelt, M., Andersen, N., and GarbeSchönberg, D., 2009. Mid-Pliocene shifts in ocean overturning circulation and the onset of Quaternary-style climates. Clim. Past, 5(2):269-283. http://www.climpast.net/5/269/2009/cp-5-269-2009.pdf

Shackleton, N.J., Fairbanks, R.G., Chiu, T.-C., and Parrenin, F., 2004. Absolute calibration of the Greenland time scale: implications for Antarctic time scales and for $\delta^{14} \mathrm{C}$. Quat. Sci. Rev., 23(14-15):1513-1522. doi:10.1016/ j.quascirev.2004.03.006

Shimada, C., Sato, T., Toyoshima, S., Yamasaki, M., and Tanimura, Y., 2008. Paleoecological significance of laminated diatomaceous oozes during the middle-to-late Pleistocene, North Atlantic Ocean (IODP Site U1304). Mar. Micropaleontol., 69(2):139-150. doi:10.1016/j.marmicro.2008.07.004

Sorrell, J., and Judge, S.A., 2007. Climate change in the North Atlantic Ocean (IODP Expedition 306, Site U1314) at ca. 1.5 Ma. Geol. Soc. Am. Abstr. Progr., 39(2):85. http://gsa.confex.com/gsa/2007SE/finalprogram/abstract_119208.htm

Stein, R., Hefter, J., Grützner, J., Voelker, A., and Naafs, B.D.A., 2009. Variability of surface water characteristics and Heinrich-like events in the Pleistocene midlatitude North Atlantic Ocean: biomarker and XRD records from IODP Site U1313 (MIS 16-9). Paleoceanography, 24(2):PA2203. doi:10.1029/2008PA001639

Stein, R., Kanamatsu, T., Alvarez-Zarikian, C., Higgins, S.M., Channell, J.E.T., Aboud, E., Ohno, M., Acton, G.D., Akimoto, K., Bailey, I., Bjørklund, K.R., Evans, H., Nielsen, S.H.H., Fang, N., Ferretti, P., Gruetzner, J., Guyodo, Y.J.B., Hagino, K., Harris, R., Hatakeda, K., Hefter, J., Judge, S.A., Kulhanek, D.K., Nanayama, F., Rashid, H., Sierro Sanchez, F.J., Voelker, A., and Zhai, Q., 2006. North Atlantic paleoceanography: the last five million years. Eos, Trans. Am. Geophys. Union, 87(13):129-133. doi:10.1029/2006E0130002

Stoner, J.S., Channell, J.E.T., and Hillaire-Marcel, C., 1995. Late Pleistocene relative geomagnetic paleointensity from the deep Labrador Sea: regional and global correlations. Earth Planet. Sci. Lett., 134(3-4):237-252. doi:10.1016/0012-821X(95)00134-X

Stoner, J.S., Channell, J.E.T., and Hillaire-Marcel, C., 1996. The magnetic signature of rapidly deposited detrital layers from the deep Labrador Sea: relationship to North Atlantic Heinrich layers. Paleoceanography, 11(3):309325. doi:10.1029/96PA00583

van Kreveld, S.A., Knappertsbusch, M., Ottens, J., Ganssen, G.M., and van Hinte, J.E., 1996. Biogenic carbonate and 
ice-rafted debris (Heinrich layer) accumulation in deepsea sediments from a Northeast Atlantic piston core. Mar. Geol., 131(1-2):21-46. doi:10.1016/00253227(95)00143-3

Voelker, A., Cavaleiro, C., Rebotim, A., Ventura, C., Hillaire-Marcel, C., and Martin, P., 2010. Surface and deep water variations and their impact on the Meridional Overturning Circulation during the mid-Brunhes as revealed at IODP Sites U1313 and U1305. Geophys. Res. Abst., 12:EGU2010-10810. http://meetingorganizer.copernicus.org/EGU2010/EGU2010-10810.pdf

Voelker, A.H.L., Rodrigues, T., Stein, R., Hefter, J., Billups, K., Oppo, D., McManus, J., and Grimalt, J.O., 2009. Variations in mid-latitude North Atlantic surface water properties during the mid-Brunhes: does marine isotope Stage 11 stand out? Clim. Past, 5:1553-1607. http:// www.clim-past-discuss.net/5/1553/2009/

Yamasaki, M., Matsui, M., Shimada, C., Chiyonobu, S., and Sato, T., 2008. Timing of shell size increase and decrease of the planktonic foraminifer Neogloboquadrina pachyderma (sinistral) during the Pleistocene, IODP Exp. 303 Site U1304, the North Atlantic Ocean. Open Paleontol. J., 1(1):18-23. doi:10.2174/1874425700801010018

Initial receipt: 17 November 2009

Acceptance: 15 March 2010

Publication: 30 June 2010

MS 303306-214 
Figure F1. Location of sites occupied during IODP Expedition 303/306.

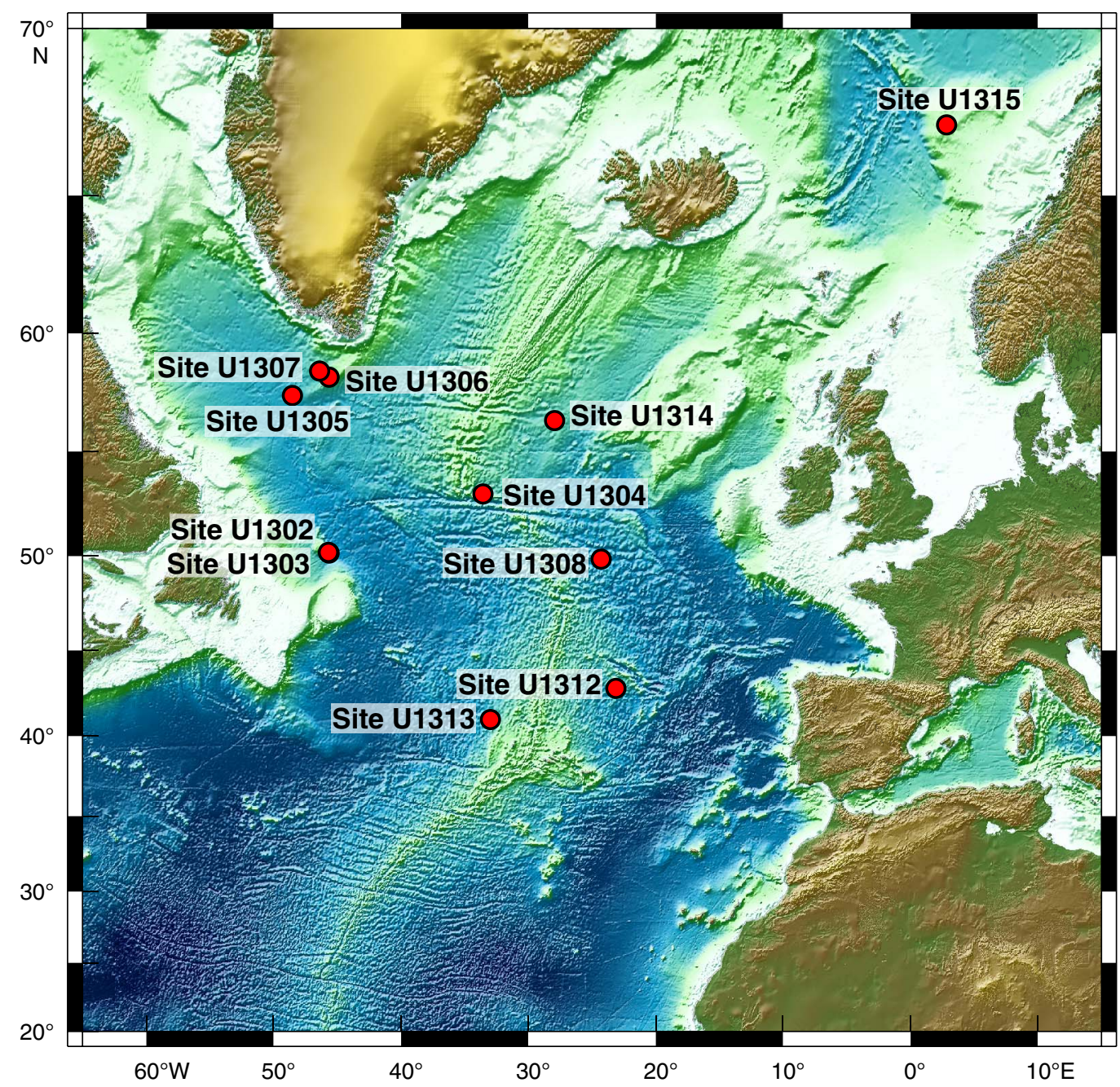


Figure F2. Summary of stratigraphies at sites occupied during IODP Expeditions (A) 303 and (B) 306, excluding Site U1315. IRD = ice-rafted debris. Blue $=$ nannofossil-based tie lines, red $=$ magnetostratigraphic tie lines. In polarity columns, black $=$ normal polarity, white $=$ reversed polarity, hatched or gray $=$ indeterminate polarity. $\mathrm{TD}=$ total depth. (Continued on next page.)

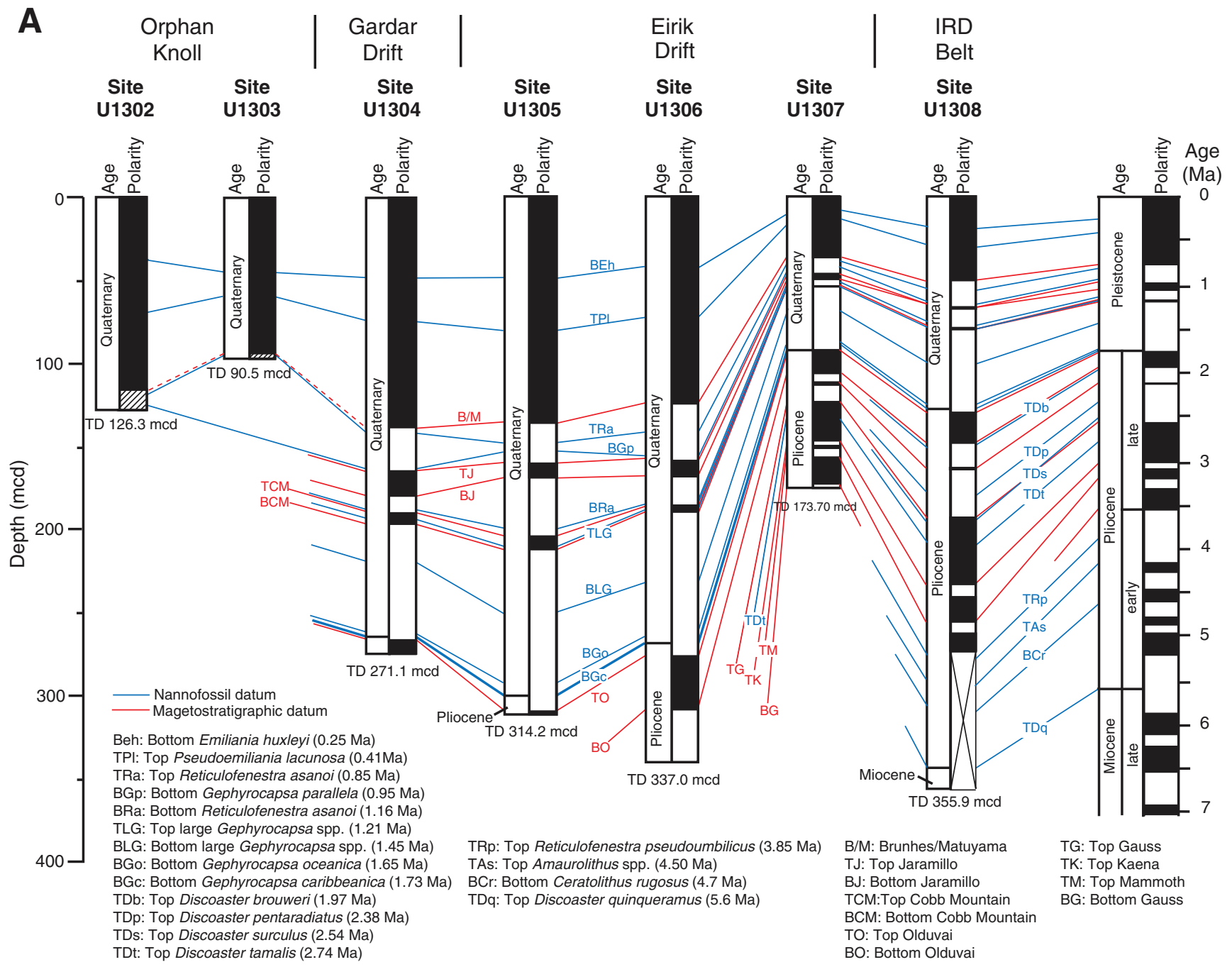


Figure F2 (continued).

B

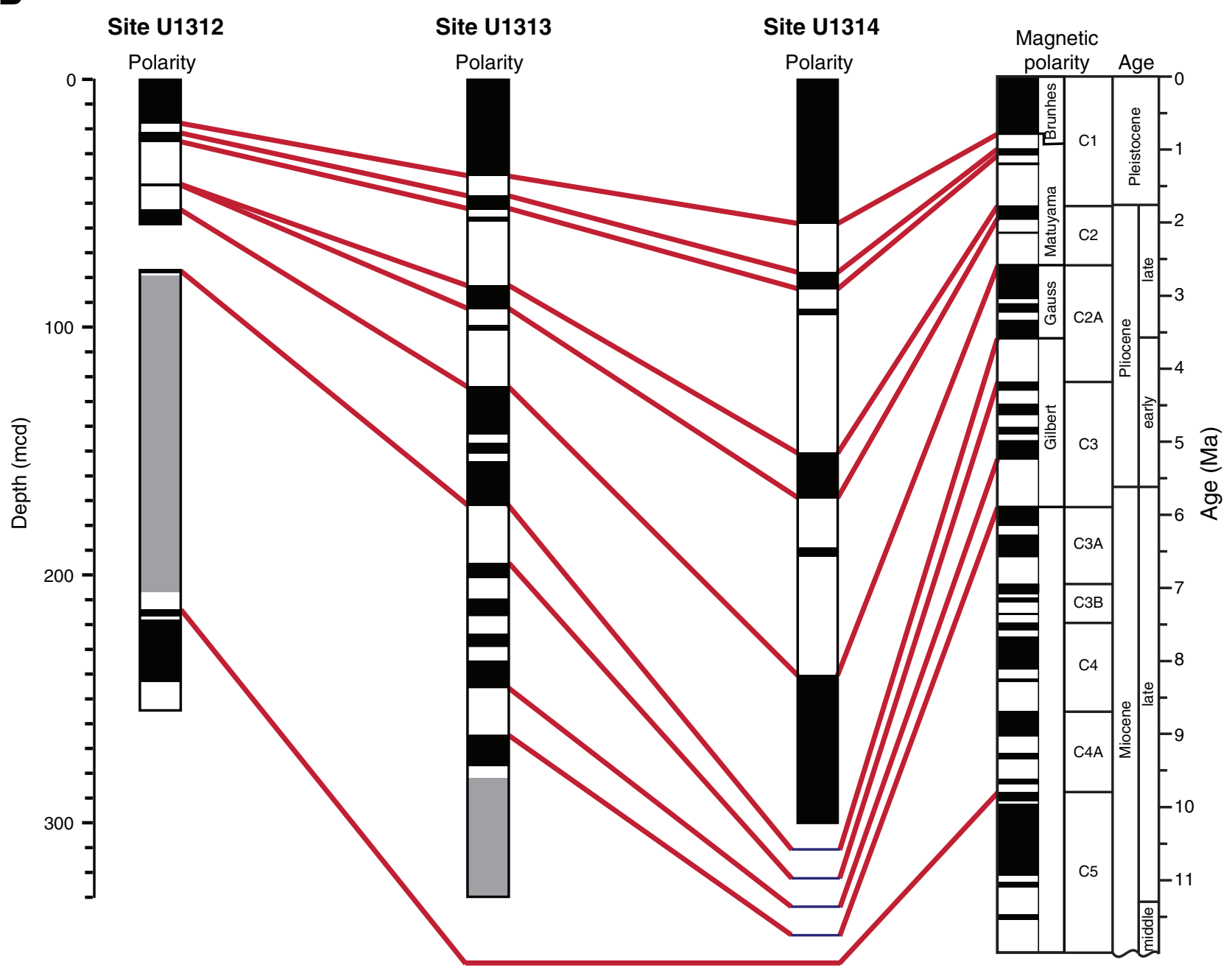


Figure F3. Comparison of percent detrital carbonate (red) and ratio of lithics to foraminifers (light green) at DSDP Site 609 (Bond et al., 1992) with XRF scanning $\mathrm{Ca} / \mathrm{Sr}$ (blue) and $\mathrm{Si} / \mathrm{Sr}$ (black), magnetic susceptibility (dark green), and bulk carbonate $\delta^{18} \mathrm{O}$ (gray) at Site U1308. Figure from Hodell et al. (2008). H1-H6 = Heinrich Events.

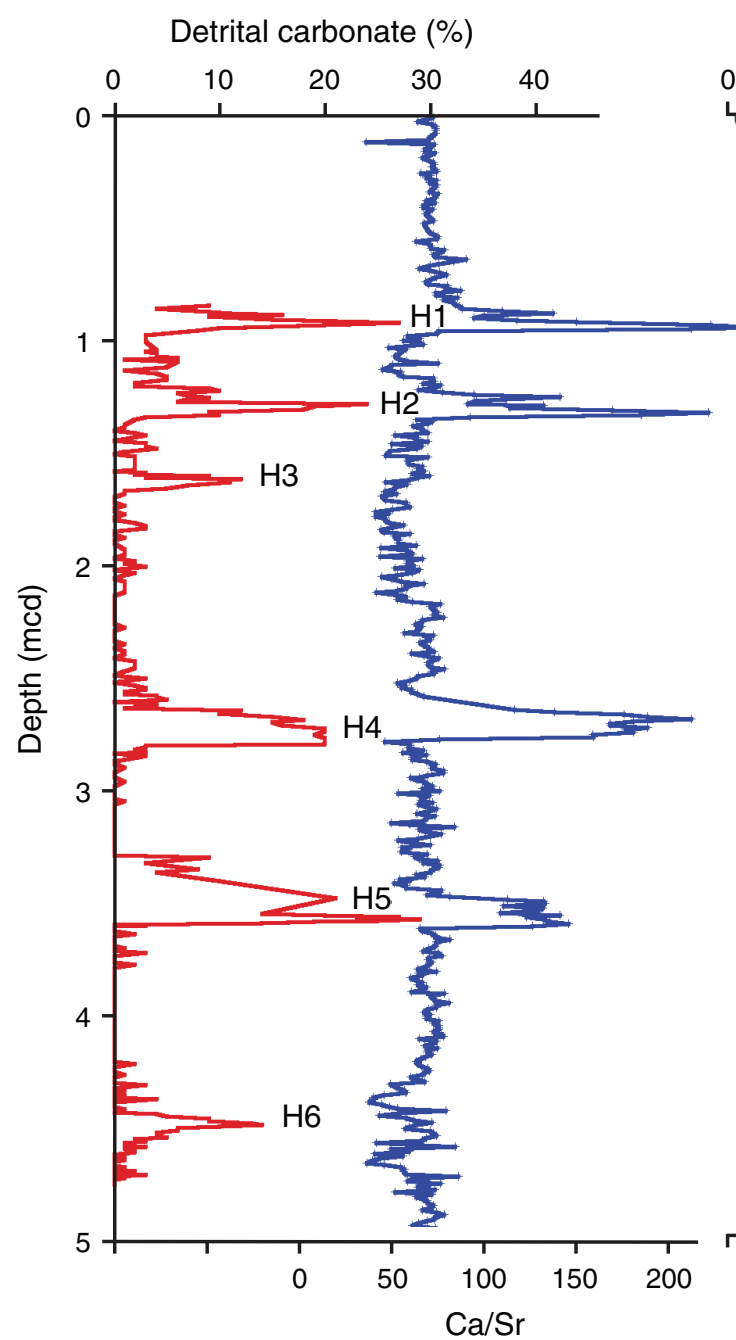

Magnetic susceptibility (SI)
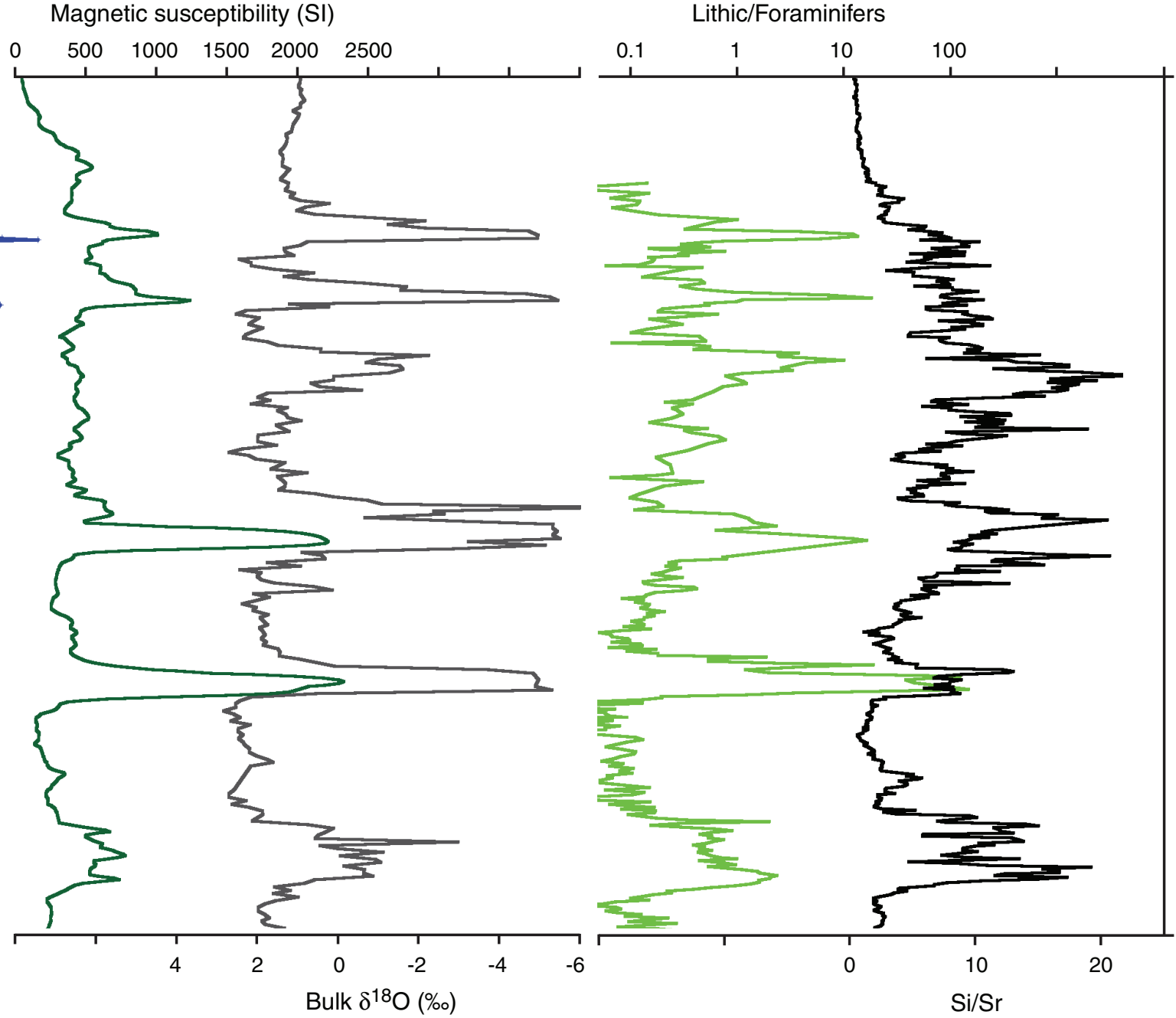
Figure F4. Magnetic susceptibility (gray), gamma ray attenuation (GRA) density (dark green), Ca/Sr (red) and $\mathrm{Si} / \mathrm{Sr}$ (blue) from XRF scanning, and bulk carbonate $\delta^{18} \mathrm{O}$ (black) and benthic $\delta^{18} \mathrm{O}$ (light green, with glacial MIS labeled) for the last 1.4 m.y. Detrital carbonate layers, marked by peaks in $\mathrm{Ca} / \mathrm{Sr}$, first occurred in MIS 16 at $\sim 640$ ka. Figure from Hodell et al. (2008).

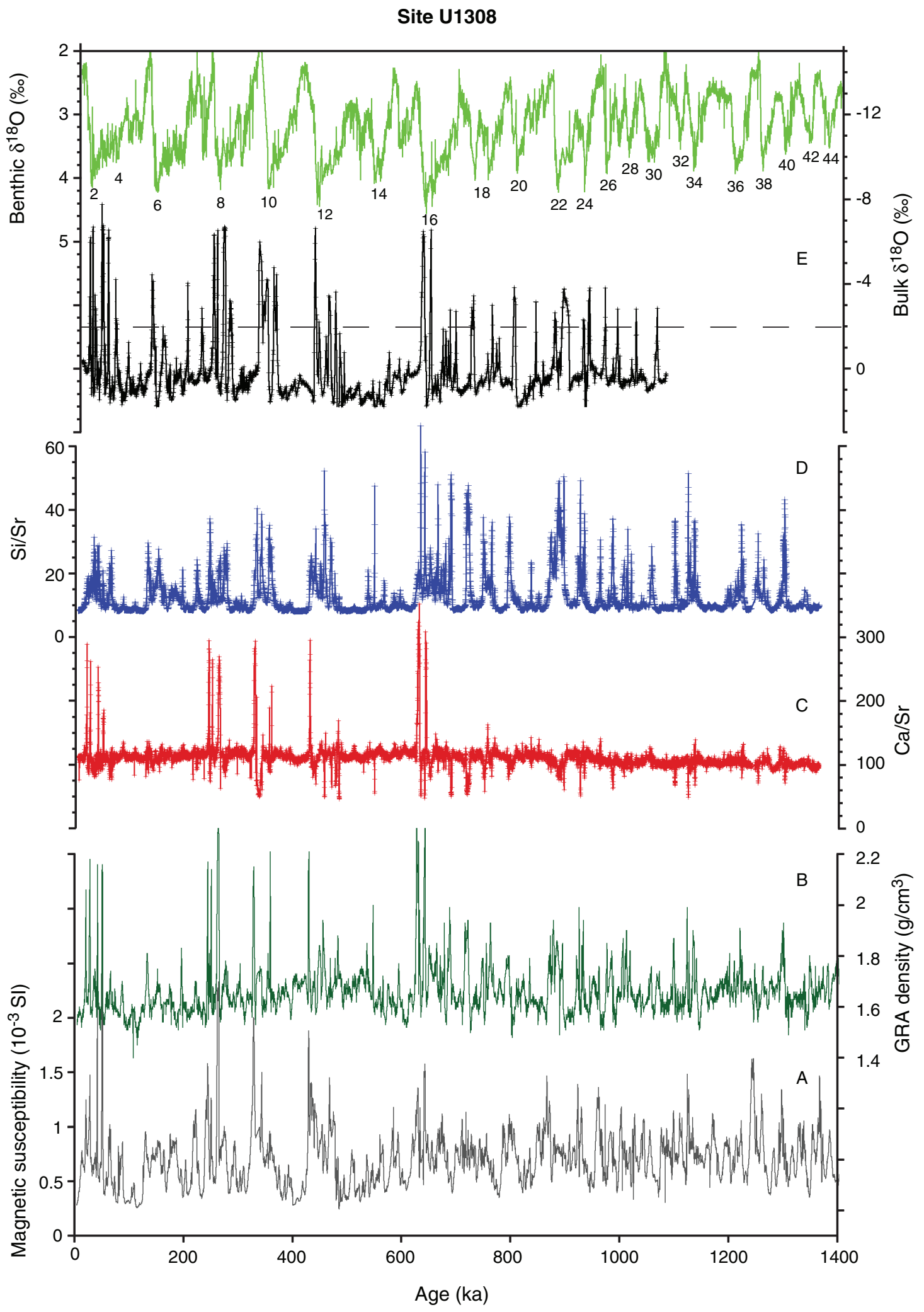


Figure F5. A. Linear correlation coefficients for slopes of natural remanent magnetization (NRM) versus anhysteretic remanent magnetization (ARM) during alternating-field demagnetization (red) and NRM demagnetization versus ARM acquisition (ARMAQ) (blue) that constitute the RPI proxies. B. Component inclination of NRM. C. Benthic $\delta^{18} \mathrm{O}$ record (red) correlated to the Lisiecki and Raymo (2005) stack (blue) by Hodell et al. (2008). Glacial MIS are labeled. D. Slopes of NRM/ARM (red) and NRM/ARMAQ (blue) for the 20-60 mT demagnetization and acquisition interval that constitute RPI proxies. Figure from Channell et al. (2008).

A

Site U1308

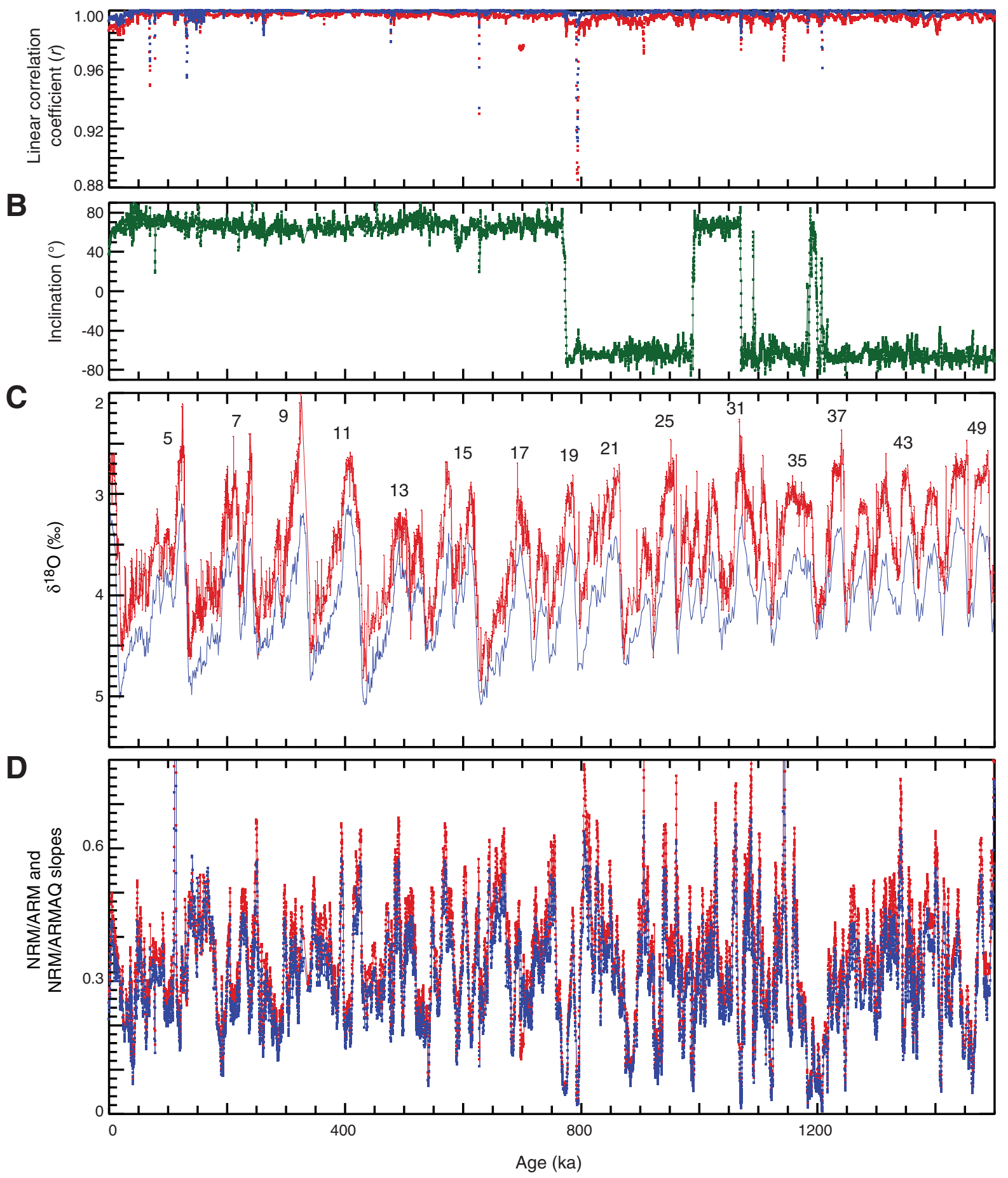


Figure F6. Three-point moving averages of total organic carbon (TOC), calcium carbonate $\left(\mathrm{CaCO}_{3}\right)$, relative (rel.) XRD intensities for dolomite, and alkenone-based sea-surface temperatures (SST). Global benthic isotope stack from Lisiecki and Raymo (2005). Marine isotope stage (MIS) and substage numbering from Bassinot et al. (1994). $\mathrm{T}=$ Termination. Orange rhombs indicate occurrence of Heinrich-like events (HE) at Site U1308 (from Hodell et al., 2008). Modern SST (from Locarnini et al., 2006) and estimated SSTs for MIS 2 and 6 are indicated. Figure from Stein et al. (2009).

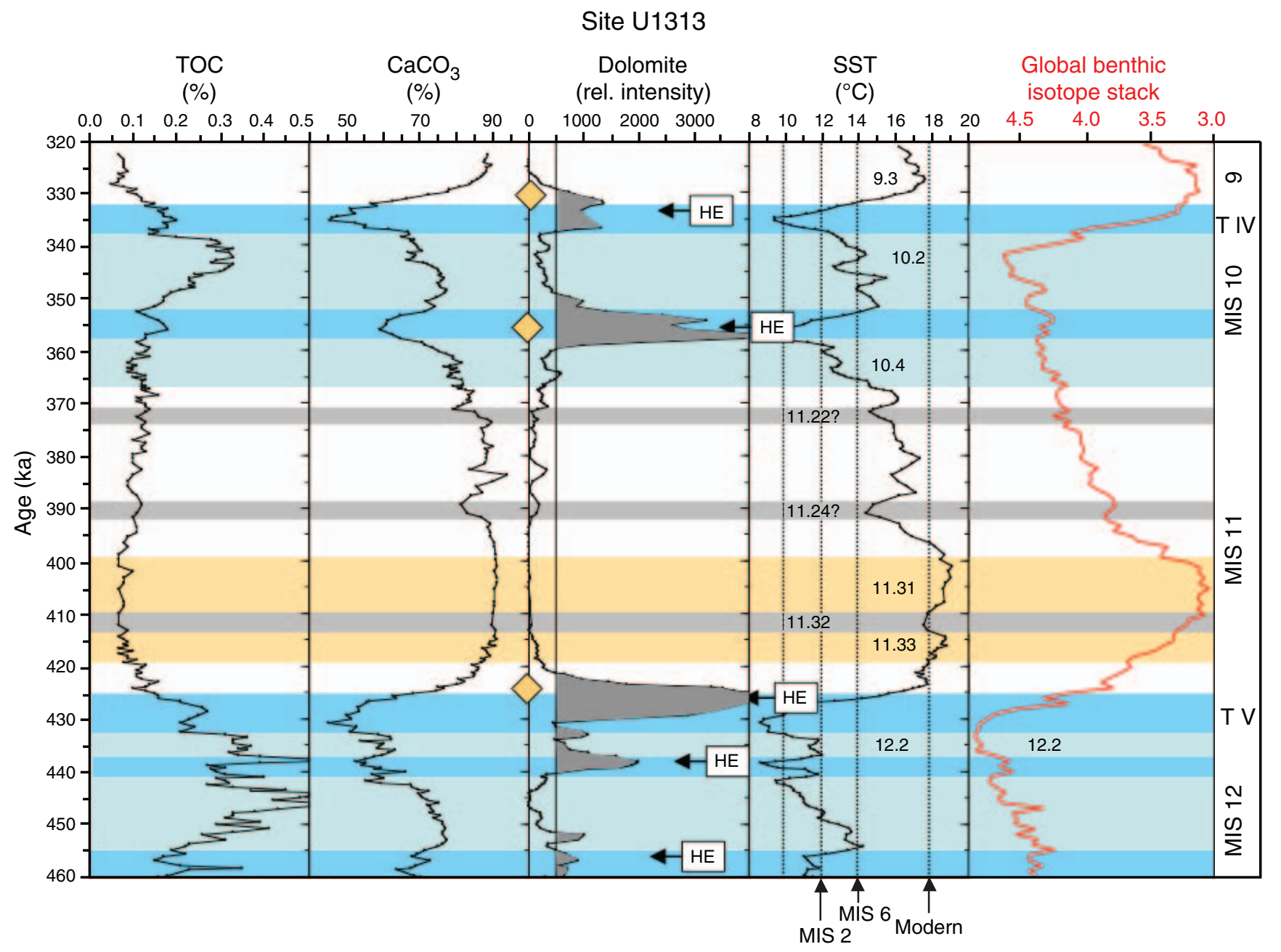


Table T1. Composite section depths and ages. (See table note.)

\begin{tabular}{lllcccc}
\hline \multirow{2}{*}{ Site } & \multicolumn{2}{c}{ Location } & $\begin{array}{c}\text { Water depth } \\
(\mathrm{mbsl})\end{array}$ & $\begin{array}{c}\text { Total depth } \\
(\mathrm{mbsf})\end{array}$ & $\begin{array}{c}\text { Composite depth } \\
(\mathrm{mcd})\end{array}$ & $\begin{array}{c}\text { Maximum } \\
\text { composite age } \\
(\mathrm{ka})\end{array}$ \\
\cline { 2 - 5 } & \multicolumn{1}{c}{ Latitude } & Longitude & 107 & 104 & $\sim 750$ \\
\hline U1302/U1303 & $50^{\circ} 10^{\prime} \mathrm{N}$ & $45^{\circ} 38^{\prime} \mathrm{W}$ & 3555 & 107 & 199 & $\sim 1300$ \\
U1304 & $53^{\circ} 3.4^{\prime} \mathrm{N}$ & $33^{\circ} 31.7^{\prime} \mathrm{W}$ & 3065 & 243 & 303 & $\sim 1600$ \\
U1305 & $57^{\circ} 28.5^{\prime} \mathrm{N}$ & $48^{\circ} 31.8^{\prime} \mathrm{W}$ & 3518 & 287 & 337 & $\sim 2100$ \\
U1306 & $58^{\circ} 14.2^{\prime} \mathrm{N}$ & $45^{\circ} 38.5^{\prime} \mathrm{W}$ & 2273 & 309 & 56 & $\sim 1200$ \\
U1307 & $58^{\circ} 30.3^{\prime} \mathrm{N}$ & $46^{\circ} 24^{\prime} \mathrm{W}$ & 2575 & 162 & 247 & $\sim 3400$ \\
U1308 & $49^{\circ} 52.7^{\prime} \mathrm{N}$ & $24^{\circ} 14.3^{\prime} \mathrm{W}$ & 3871 & 341 & 0 & $\mathrm{NA}$ \\
U1312 & $42^{\circ} 50.2^{\prime} \mathrm{N}$ & $23^{\circ} 5.2^{\prime} \mathrm{W}$ & 3554 & 248 & 301 & $\sim 6700$ \\
U1313 & $41^{\circ} 0.1^{\prime} \mathrm{N}$ & $32^{\circ} 57.4^{\prime} \mathrm{W}$ & 3426 & 308 & 281 & $\sim 2800$ \\
U1314 & $56^{\circ} 21.9^{\prime} \mathrm{N}$ & $27^{\circ} 53.3^{\prime} \mathrm{W}$ & 2820 & 280 & $\mathrm{NA}$ & $\mathrm{NA}$ \\
U1315 & $67^{\circ} 12.7^{\prime} \mathrm{N}$ & $2^{\circ} 56.2^{\prime} \mathrm{E}$ & 1280 & 179 & & \\
\hline
\end{tabular}

Note: NA = not applicable. 